\title{
A Conceptual Framework for Effectively Anticipating Water-Quality Changes Resulting From Changes in Agricultural Activities
}

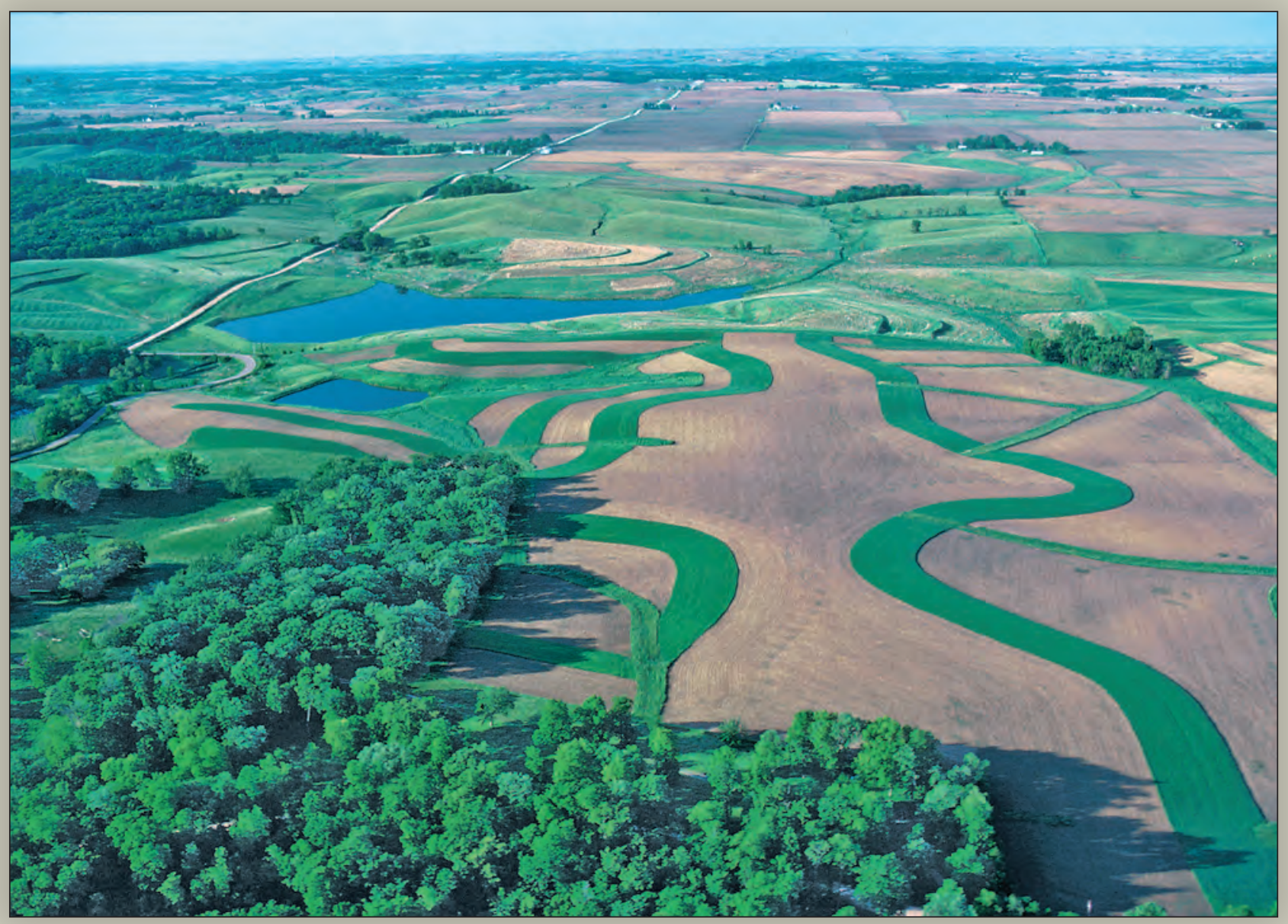

Scientific Investigations Report 2017-5095

U.S. Department of the Interior

U.S. Geological Survey 
Cover: An upstream small dam, terraces, buffer strips, grass plantings and other conservation measures are part of a project designed to improve the quality of water entering Union Grove Lake in Tama County, lowa (U.S. Department of Agriculture, 2011). 


\section{A Conceptual Framework for Effectively Anticipating Water-Quality Changes Resulting From Changes in Agricultural Activities}

By Paul D. Capel, David M. Wolock, Richard H. Coupe, and Jason L. Roth

Scientific Investigations Report 2017-5095 


\title{
U.S. Department of the Interior \\ RYAN K. ZINKE, Secretary
}

\section{U.S. Geological Survey William H. Werkheiser, Deputy Director exercising the authority of the Director}

\author{
U.S. Geological Survey, Reston, Virginia: 2018
}

For more information on the USGS - the Federal source for science about the Earth, its natural and living resources, natural hazards, and the environment-visit https://www.usgs.gov or call 1-888-ASK-USGS.

For an overview of USGS information products, including maps, imagery, and publications,

visit https://store.usgs.gov.

Any use of trade, firm, or product names is for descriptive purposes only and does not imply endorsement by the U.S. Government.

Although this information product, for the most part, is in the public domain, it also may contain copyrighted materials as noted in the text. Permission to reproduce copyrighted items must be secured from the copyright owner.

Suggested citation:

Capel, P.D., Wolock, D.M., Coupe, R.H., and Roth, J.L., 2018, A conceptual framework for effectively anticipating water-quality changes resulting from changes in agricultural activities: U.S. Geological Survey Scientific Investigations Report 2017-5095, 35 p., https://doi.org/10.3133/sir20175095.

ISSN 2328-0328 (online) 


\title{
Foreword
}

Sustaining the quality of the Nation's water resources and the health of our diverse ecosystems depends on the availability of sound water-resources data and information to develop effective, science-based policies. Effective management of water resources also brings more certainty and efficiency to important economic sectors. Taken together, these actions lead to immediate and long-term economic, social, and environmental benefits that make a difference to the lives of the almost 400 million people projected to live in the United States by 2050.

In 1991, Congress established the U.S. Geological Survey National Water-Quality Assessment (NAWQA) to address where, when, why, and how the Nation's water quality has changed, or is likely to change in the future, in response to human activities and natural factors. Since then, NAWQA has been a leading source of scientific data and knowledge used by national, regional, state, and local agencies to develop science-based policies and management strategies to improve and protect water resources used for drinking water, recreation, irrigation, energy development, and ecosystem needs. Plans for the third decade of NAWQA (2013-23) address priority water-quality issues and science needs identified by NAWQA stakeholders, such as the Advisory Committee on Water Information and the National Research Council, and are designed to meet increasing challenges related to population growth, increasing needs for clean water, and changing land-use and weather patterns.

This report describes a conceptual framework of how agricultural activities interact with the hydrologic environment in determining attainable expectations for improving water quality. The framework is based on generalized concepts describing the movement of water, the environmental behavior of chemicals and eroded soil, and the designed functions of various agricultural activities.

We hope this publication will provide you with insights and information to meet your waterresource needs and will foster increased citizen awareness and involvement in the protection and restoration of our Nation's waters. The information in this report is intended primarily for those interested or involved in resource management and protection, conservation, regulation, and policymaking at the regional and national levels.

\author{
Dr. Donald W. Cline \\ Associate Director for Water \\ U.S. Geological Survey
}





\section{Contents}

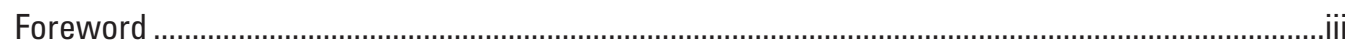

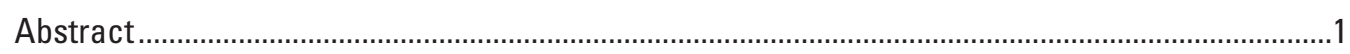

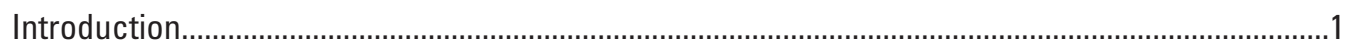

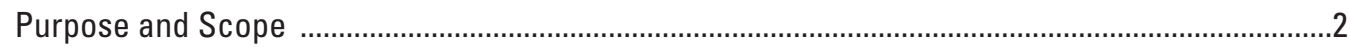

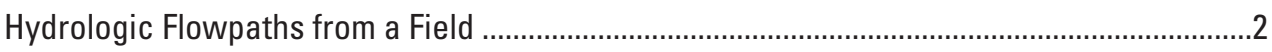

Quantifying Flowpath Contributions to a Stream......................................................................

Examples of Three Streams with Different Characteristic Flowpaths.....................................7

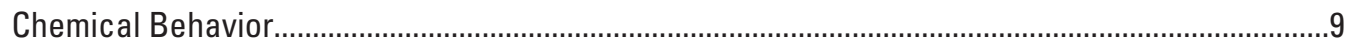

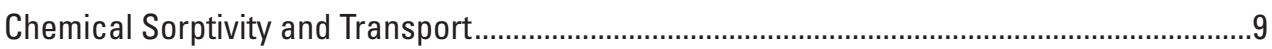

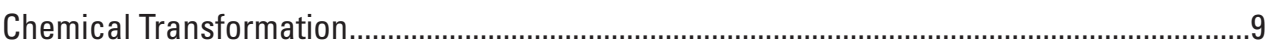

Combining Sorptivity, Transformation, and Hydrologic Transit Times....................................11

Field and Model Observations of Chemicals and Sediment in Relation to Agricultural

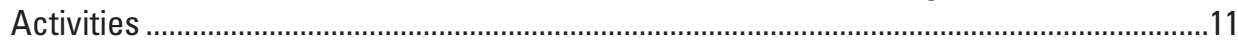

Choice of Agricultural Activities in the Context of Hydrologic Setting and Chemical Behavior .................................................................................................................

Agricultural Activity Decision Tree as an Organizing Tool.....................................................14

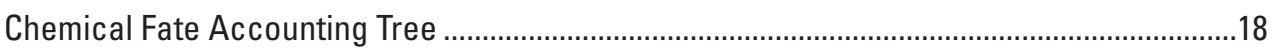

Summary

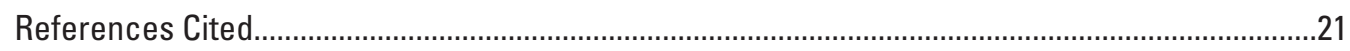

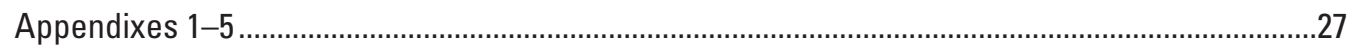

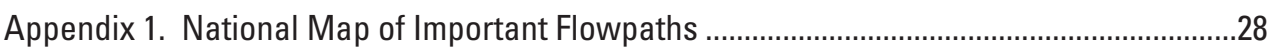

Appendix 2. Maps of Hydrologic Transit Times in Small Watersheds .................................29

Appendix 3. Extent of Association with Sediment and Environmental Half-Lives for Selected Chemicals Related to Agriculture...............................................................30

Appendix 4. Selected Studies of the Effect of Agricultural Management Practices on the Movement of Chemicals and Sediments Out of the Field .................................32

Appendix 5. Agricultural Activity Decision Tree as an Organizing Tool Including Vertical Inlets to Subsurface Drains ...........................................................................34 


\section{Figures}

1. Diagrams of the water flowpaths from the landscape to the stream where fastflow is important, slowflow is important, and drainflow is important.

2. Diagrams showing the continua of water flowpaths from landscape to stream combined with the sorption continuum from 100 percent water-associated to 100 percent sediment-associated.....

3. A conceptual map of the conterminous United States showing areas of crop agriculture expected to have slowflow, fastflow, and drainflow as their characteristic flowpaths

4. Precipitation, streamflow, and calculated baseflow for a 1-year period for the three example streams: slowflow-fed stream, fastflow-fed stream, and drainflowfed stream

5. Estimated hydrologic transit times for the characteristic flowpath for the three example streams based on the conceptual framework.

6. Lines of percent chemical-loss as a function of hydrologic transit time and chemical half-life

7. Environmental half-life and percentage of various agricultural chemicals in water .....11

8. Estimated increases in infiltration and decreases in sediment yield alongside a change in an agricultural management practice based on the results of the Water Erosion Prediction Project (WEPP) model.

9. A simple decision tree for determining which agricultural activities can protect and improve water quality in a local stream from the movement of a given chemical (or sediment) and which agricultural activities could be counterproductive...

10. A simple decision tree for determining the agricultural activities that could protect and improve water quality with regard to a water-associated chemical (like nitrate) in a stream where slow flowpaths (groundwater) are an important component of total streamflow.

11. A simple decision tree for determining the agricultural activities that could protect and improve water quality with regard to sediment in streams where fast flowpaths (surface runoff) are an important component of total streamflow, at least for part of the year...

12. A chemical fate accounting tree for eroded soil .....

\section{Tables}

1. Summary of the conceptual framework for the hydrologic and chemical characteristics of water moving from a field or watershed through fastflow, slowflow, and drainflow.

2. Selected examples of water-associated and sediment-associated agricultural chemicals

3. Selected examples of agricultural management practices and other agricultural activities used to help minimize chemical and sediment loss to protect and improve water quality. 


\section{Conversion Factors}

International System of Units to U.S. customary units

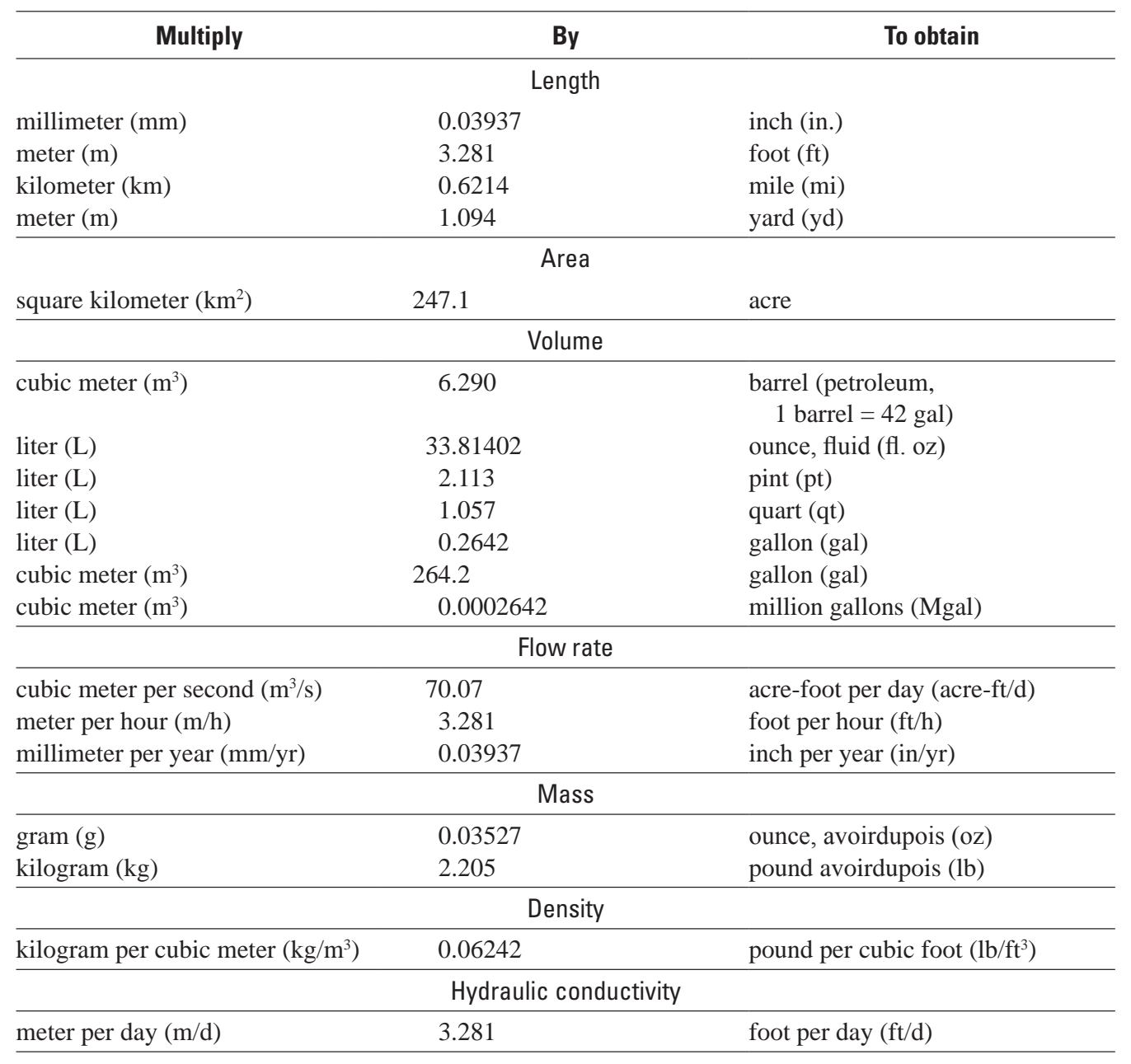




\section{Abbreviations}

\begin{tabular}{ll} 
BFI & base flow index \\
BOD & biochemical oxygen demand \\
CDL & Cropland Data Layer \\
CRP & Conservation Reserve Program \\
DDE & dichlorodiphenyldichloroethylene \\
DDT & dichlorodiphenyltrichloroethane \\
DEM & digital elevation model \\
DF & drainflow \\
FF & fastflow \\
GHG & greenhouse gases \\
GIS & geographic information system \\
Kd & sediment-water distribution coefficient \\
KINEROS & Kinematic Runoff and Erosion model \\
KOC & Soil adsorption coefficient \\
N & nitrogen \\
NHD & National Hydrography Dataset \\
NOAA & National Oceanic and Atmospheric Administration \\
NRCS FOTG & Natural Resources Conservation Service's Field Office Technical Guide \\
NRI & Natural Resources Inventory \\
P & phosphorous \\
PAM & polyacrylamide \\
sec & second \\
SF & slowflow \\
SS & suspended sediment \\
STATSGO & Natural Resources Conservation Service State Soil Geographic \\
USGS & U.S. Geological Survey \\
WEPP & Water Erosion Prediction Project \\
yr & year \\
\hline
\end{tabular}




\title{
A Conceptual Framework for Effectively Anticipating Water-Quality Changes Resulting From Changes in Agricultural Activities
}

\author{
By Paul D. Capel, David M. Wolock, Richard H. Coupe, and Jason L. Roth
}

\section{Abstract}

Agricultural activities can affect water quality and the health of aquatic ecosystems; many water-quality issues originate with the movement of water, agricultural chemicals, and eroded soil from agricultural areas to streams and groundwater. Most agricultural activities are designed to sustain or increase crop production, while some are designed to protect soil and water resources. Numerous soil- and water-protection practices are designed to reduce the volume and velocity of runoff and increase infiltration. This report presents a conceptual framework that combines generalized concepts on the movement of water, the environmental behavior of chemicals and eroded soil, and the designed functions of various agricultural activities, as they relate to hydrology, to create attainable expectations for the protection of - with the goal of improving — water quality through changes in an agricultural activity.

The framework presented uses two types of decision trees to guide decision making toward attainable expectations regarding the effectiveness of changing agricultural activities to protect and improve water quality in streams. One decision tree organizes decision making by considering the hydrologic setting and chemical behaviors, largely at the field scale. This decision tree can help determine which agricultural activities could effectively protect and improve water quality in a stream from the movement of chemicals, or sediment, from a field. The second decision tree is a chemical fate accounting tree. This decision tree helps set attainable expectations for the permanent removal of sediment, elements, and organic chemicals — such as herbicides and insecticides - through trapping or conservation tillage practices. Collectively, this conceptual framework consolidates diverse hydrologic settings, chemicals, and agricultural activities into a single, broad context that can be used to set attainable expectations for agricultural activities. This framework also enables better decision making for future agricultural activities as a means to reduce current, and prevent new, water-quality issues.

\section{Introduction}

Agriculture in the United States supplies much of the world's human food, animal feed, fuel, and fiber needs. Over time, agriculture has expanded in area, intensified in production, and changed the national landscape.

Agricultural activities affect the quality of water, air, and soil, and the overall health of natural ecosystems. Many water-quality effects—algal blooms, toxicity to aquatic organisms, eutrophication, turbidity, changes in stream habitat, degradation of recreational waters, decreased quality of fisheries, contamination of drinking water supplies, and hypoxia in coastal areas-originate with the movement of water, agricultural chemicals, and eroded soil from agricultural areas into streams and groundwater. Adverse water-quality effects often result from an excess of a chemical, or sediment, in a water resource when compared with its natural background concentration.

The movement of water is the primary mechanism by which agricultural chemicals and eroded soil move from agricultural areas to nonagricultural areas. Water from individual fields aggregates to form streams and, eventually, major rivers. Streams integrate all water flowpaths across and through a landscape. Agricultural chemicals can move into and through every component of the hydrologic system. The movement of chemicals and eroded soil from agricultural areas can be minimized by management decisions that are based on an understanding of the connections between the movement of water and various agricultural activities. This practice is especially effective for critical source areasareas within a field or catchment vulnerable to the loss of agricultural chemicals and sediment (Gburek and Sharpley, 1998; Sharpley and others, 2003; Kleinman and others, 2011).

Agricultural activities comprise all farming procedures leading to the production of crops or animals. These activities include growing and harvesting crops and animals, landscape modifications, applying chemicals, and waste disposal. 
Agricultural activities fulfill crop or animal requirements and could protect soil or water resources. Some of these activities are called agricultural management practices and are used to protect soil and water resources (U.S. Department of Agriculture, Natural Resources Conservation Service, 2014a). Many soil- and water-protection practices are designed to reduce, slow, and(or) redirect runoff and increase infiltration (as with terraces, grassed waterways, and buffers). Some are designed to be long-term features of the landscape (as with terraces, buffers, drainage, and irrigation), and some are designed to be implemented annually (as with crops, tillage, and chemical use).

At times, agricultural activities-both those designed to improve crop productivity and those designed to protect water and soil resources—can unintentionally degrade water quality. For example, the installation of subsurface drainage greatly improves a producer's access to fields during critical planting periods in the spring, but can also short-circuit soil denitrification and move nitrogen and herbicides directly into streams (Blann and others, 2009). Another example is conservation tillage. No-till practices have effectively improved soil structure and reduced sediment runoff, but they also can increase the movement of nutrients and pesticides into streams (Devlin and Barnes, 2009; Verbree and others, 2010; Margulies, 2012).

Agricultural activities often affect local water flowpaths, which in turn control the extent of chemicals and eroded soil losses from the field (Capel and others, in press). However, the resulting change in water flowpaths is not always considered during the choice and implementation of agricultural activities designed to prevent the loss of a specific chemical. With some agricultural activities, preventing or reducing the loss of one chemical or sediment may enhance the loss of another. This outcome can lead to situations where expectations are not met, and water, chemicals, and sediment move in unexpected ways.

\section{Purpose and Scope}

This report presents a conceptual framework for establishing attainable expectations for the protection and improvement of water quality that can result from a change in agricultural management practices. The framework integrates water movement, the environmental behavior of agricultural chemicals and sediment, and the designed functions of various agricultural activities. Assumptions related to the expected (1) water flowpaths, (2) behavior and transport of chemicals and sediment, and (3) effects of a specific agricultural activity on corresponding flow and transport processes are the basis for this framework. Two types of decision trees were designed using this framework. These decision trees can serve as guides for establishing informed expectations about the outcomes of changes in agricultural activities and how these changes can protect or improve water quality in streams.
The first aspect of this framework organizes decisions based on hydrologic setting and chemical behaviors, largely at the field scale. The second aspect of this framework organizes decisions based on chemical fate as a means for establishing attainable expectations about the permanent removal of sediment, elements (such as nitrogen, phosphorus, and carbon), and organic chemicals (such as herbicides and insecticides) from runoff through trapping or conservation tillage practices. For both aspects, an understanding of the hydrologic setting and the behavior of the chemicals of interest can suggest which agricultural activities are most effective for protecting and improving water quality and which activities might be counterproductive. Overall, this framework consolidates diverse hydrologic settings, chemicals, and agricultural activities into a single, broad context to determine attainable expectations for current agricultural activities and enable better decision making for the future.

\section{Hydrologic Flowpaths from a Field}

The water input to a field, through rainfall and irrigation, is lost by evapotranspiration, infiltration, and runoff (as overland and shallow subsurface flow). Water lost through evapotranspiration often accounts for the majority of the input water, but the water that becomes runoff or infiltration, is the most important from a water-quality perspective. The amount and intensity of rainfall, combined with landscape characteristics such as slope, soil type, vegetation, and underlying aquifer type determine the partitioning between runoff and infiltration, as well as the rate water moves along these flowpaths.

Runoff flowpaths are primarily fast (fastflow) and are sometimes high energy. In contrast, infiltration and groundwater recharge flowpaths are often much slower (slowflow). Engineered subsurface (tile) drainage is another flowpath from a field and is termed drainflow (fig. 1). Subsurface drains are designed to move excess water out of the soil root zone and provide storage capacity for subsequent storms. After a rain event, subsurface drainage creates fast flowpaths to the stream, via percolation and lateral movement, for areas near the drains. However, in areas of the field far from the subsurface drains, flowpaths are slower because the distances across which lateral movement occurs are greater.

The extent and duration of water contact with the soil differ among these three flowpaths (table 1). Fastflow contacts only the surface or upper layers of the soil for short periods of time (hours to days). Slowflow, via infiltration and movement through an aquifer that eventually discharges into a stream or coastal area, directly contacts the soil or aquifer particles for long periods (months to decades or more). There are other slow flowpaths, such as those through wetlands, which involve varying degrees of contact with the soil. In the case of drainflow, the water contacts only the soil root zone and the upper layers of the soil-commonly 1 meter in the Eastern and Midwest United States—-before it reaches the drain. 

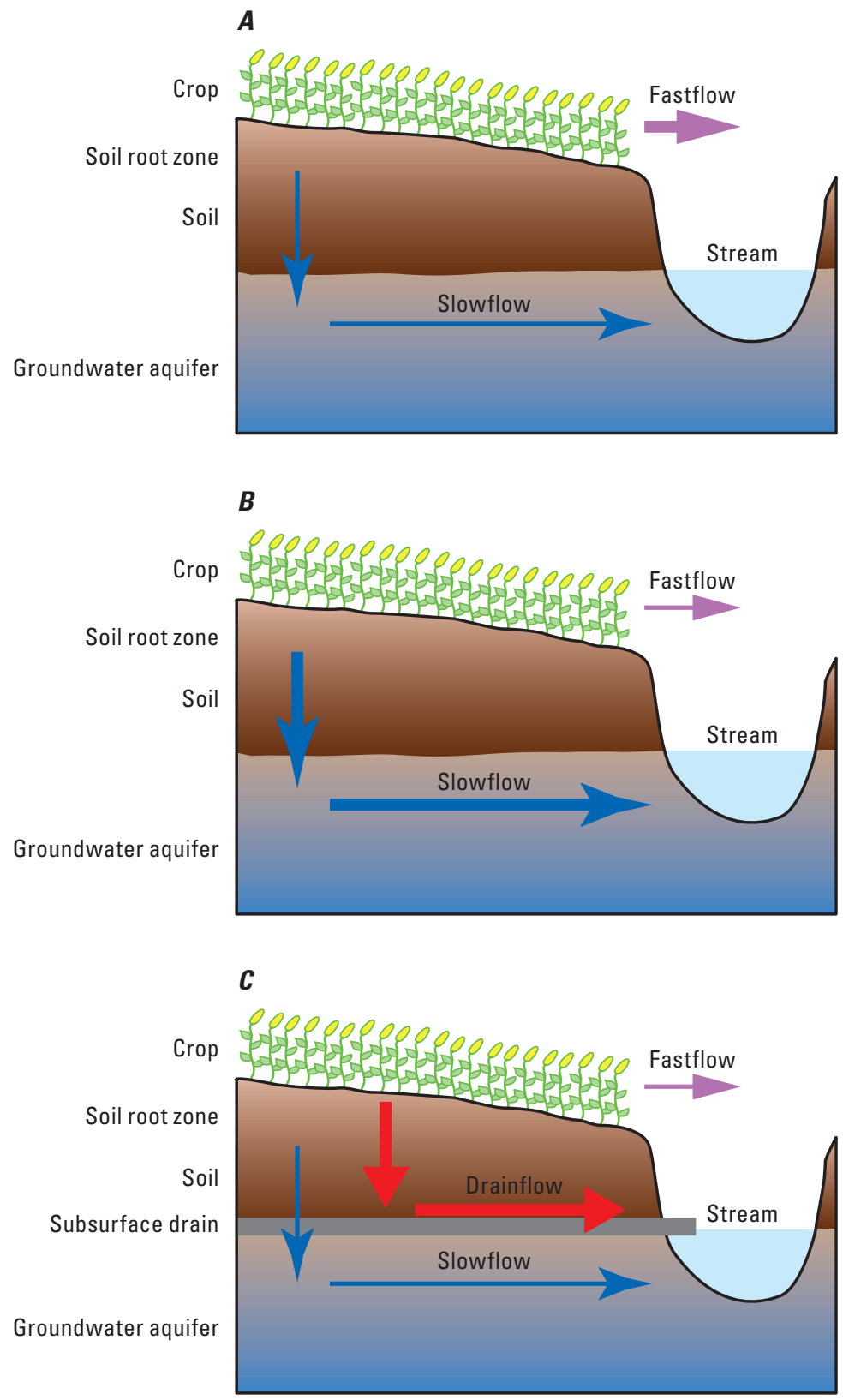

Figure 1. Water flowpaths from the landscape to the stream where $(A)$ fastflow is important, $(B)$ slowflow is important, and $(C)$ drainflow is important. 
Table 1. Summary of the conceptual framework for the hydrologic and chemical characteristics of water moving from a field or watershed through fastflow, slowflow, and drainflow.

\begin{tabular}{|c|c|c|c|}
\hline & Fastflow & Slowflow & Drainflow $^{1}$ \\
\hline $\begin{array}{l}\text { Hydrologic transit time to stream from fast } \\
\text { flowpaths after rainfall }{ }^{2}\end{array}$ & $\begin{array}{l}\text { Fast } \\
\text { (hours to days) }\end{array}$ & - & $\begin{array}{l}\text { Without vertical inlets: fast (hours to days) } \\
\text { With vertical inlets: fast (hours to days) }\end{array}$ \\
\hline $\begin{array}{l}\text { Hydrologic transit time to stream from slow } \\
\text { flowpaths after rainfall }\end{array}$ & - & $\begin{array}{l}\text { Slow (months to } \\
\text { decades) }\end{array}$ & $\begin{array}{l}\text { Without vertical inlets: intermediate (days } \\
\text { to years) } \\
\text { With vertical inlets: - }\end{array}$ \\
\hline $\begin{array}{l}\text { Age of water delivered to stream at/near } \\
\text { stream baseflow }\end{array}$ & $\begin{array}{l}\text { Young (or no } \\
\text { water) }\end{array}$ & $\begin{array}{l}\text { Old (months to } \\
\text { decades) }\end{array}$ & $\begin{array}{l}\text { Without vertical inlets: intermediate (days } \\
\text { to years) } \\
\text { With vertical inlets: fast (hours to days) }\end{array}$ \\
\hline $\begin{array}{l}\text { Percent of water delivered to stream from slow } \\
\text { flowpaths at or near stream baseflow }\end{array}$ & $\sim 0$ percent & 100 percent & 100 percent ${ }^{3}$ \\
\hline $\begin{array}{l}\text { Extent of water in contact with surface soil and } \\
\text { soil in root and unsaturated zones subsurface }\end{array}$ & $\begin{array}{l}\text { Surface/ near } \\
\text { surface only }\end{array}$ & Soil column to aquifer & $\begin{array}{l}\text { Without vertical inlets: soil column to } \\
\text { depth of subsurface drain } \\
\text { With vertical inlets: none }\end{array}$ \\
\hline $\begin{array}{l}\text { Duration of water contact time with soil in } \\
\text { root and unsaturated zones }\end{array}$ & None or quick & $\begin{array}{l}\text { Long (time of recharge } \\
\text { to aquifer) }\end{array}$ & $\begin{array}{l}\text { Without vertical inlets: Intermediate (time } \\
\text { of recharge to depth of drain, } \sim 1 \mathrm{~m} \text { ) } \\
\text { With vertical inlets: none }\end{array}$ \\
\hline $\begin{array}{l}\text { Potential for removal of sediment and } \\
\text { sediment-associated chemicals while in the } \\
\text { flowpath to the stream due to sorption and } \\
\text { filtration processes within the field/watershed }\end{array}$ & Low-moderate & High & $\begin{array}{l}\text { Without vertical inlets: high } \\
\text { With vertical inlets: very low }\end{array}$ \\
\hline $\begin{array}{l}\text { Potential for removal of a chemical due to } \\
\text { transformation reactions while in the } \\
\text { flowpath to the stream }\end{array}$ & Low & High & $\begin{array}{l}\text { Without vertical inlets: low-moderate } \\
\text { With vertical inlets: very low }\end{array}$ \\
\hline $\begin{array}{l}\text { Duration of chemical contact in an environment } \\
\text { with no or low dissolved oxygen concentrations } \\
\text { (reduced conditions) }\end{array}$ & Low & Potentially high & $\begin{array}{l}\text { Without vertical inlets: low } \\
\text { With vertical inlets: low }\end{array}$ \\
\hline
\end{tabular}

${ }^{1}$ In some areas, vertical inlets directly connect water collected in topographical depressions on the landscape to the horizontal subsurface drains. These inlets add another type of flowpath that directly connects the landscape to the stream.

${ }^{2}$ The hydrologic transit time is the elapsed time between the appearance of water at the land surface and when it appears in the stream.

${ }^{3}$ Water is slowly released through subsurface drain network, assuming the aquifer is not in contact with the stream.

\section{Quantifying Flowpath Contributions to a Stream}

Water in a stream is a mixture of water from various sources flowing through the landscape. The flowpaths that move water from the landscape are the same that deliver it to the stream. Fastflow has short-duration flowpaths (for example, runoff or direct rainfall on a stream) from the landscape and results from precipitation or snowmelt. Slowflow has long-duration flowpaths that lead to a relatively steady discharge of water into a stream (for example, groundwater discharge and wetland release). The mixture of slowflow and fastflow contributions to streams are quantified by hydrograph separation methods based on analysis of the stream hydrograph (Wahl and Wahl, 1995; Sloto and Crouse, 1996; Eckhardt, 2005). Using these separation methods, the sources of water for a stream are described as ranging from an end-member of 100 percent slowflow to another end-member of 100 percent fastflow. Flow in all streams is located along this continuum (fig $2 A$ ). 
$\boldsymbol{A}$

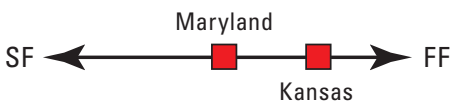

C

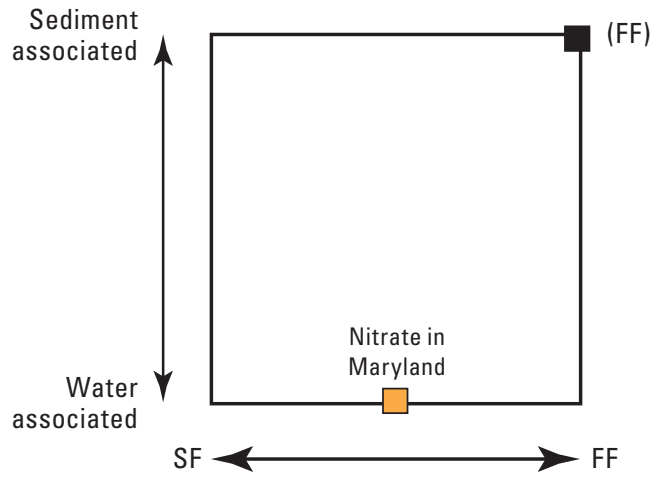

B

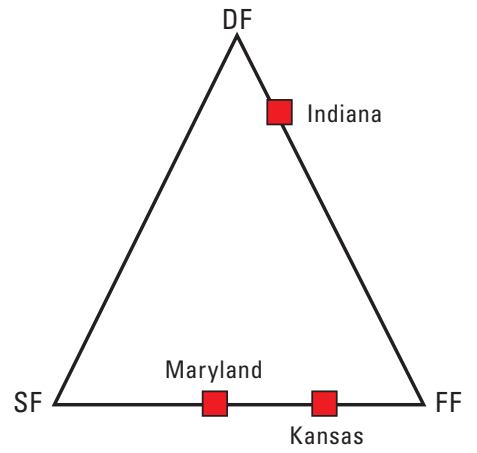

D

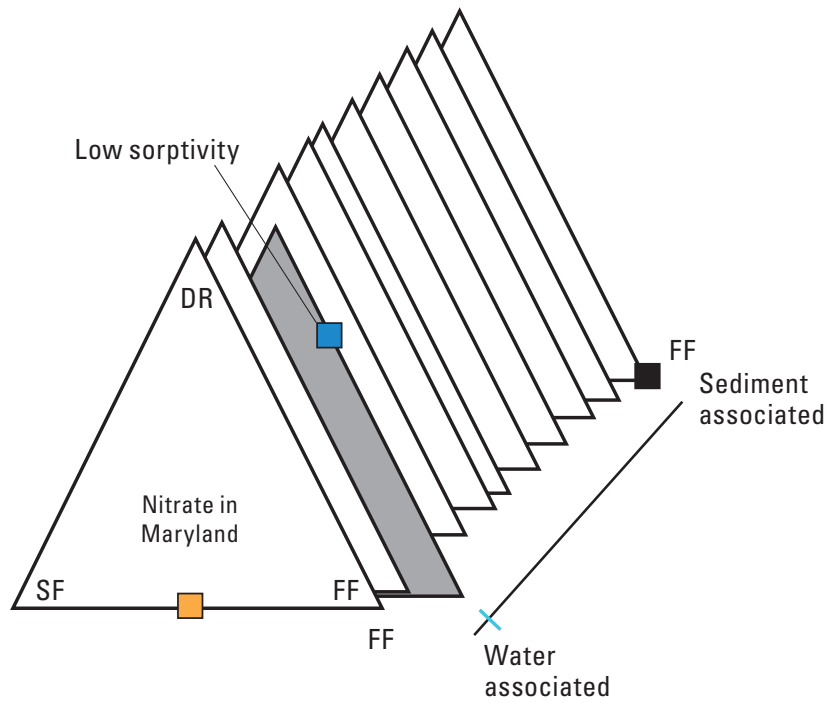

Figure 2. Continua of water flowpaths from landscape to stream combined with the sorption continuum from 100 percent waterassociated to 100 percent sediment-associated.

A. For watersheds without subsurface drainage, the water flowpaths fall on the linear continuum defined by slowflow (SF) and fastflow (FF) end-members.

$B$. For watersheds with subsurface drainage, the water flowpaths are described by a triangular space defined by the three end-members: slowflow, fastflow, and drainflow (DF).
C. In combining chemical sorptivity and water flowpaths, any chemical or sediment in any stream with only slowflow and fastflow is contained within the space described by a rectangle.

D. Any chemical or sediment in any stream with slowflow, fastflow, and drainflow is contained within the space described by a triangular prism.

The red squares in $(A)$ and $(B)$ represent the annual contributions of slowflow, fastflow, and (or) drainflow for the three example streams (Chesterville Branch, Maryland (slowflow); Indian Creek, Kansas (fastflow); Leary-Weber Ditch, Indiana (drainflow) described in the text. The yellow squares in $(C)$ and $(D)$ represent nitrate in Chesterville Branch, Maryland.

The black squares in $(C)$ and $(D)$ represent sediment in a stream receiving its water from fastflow. The blue square in $(D)$ illustrates an example of a chemical with a low degree of sorptivity 
Drainflow (via engineered subsurface drainage) has slowflow and fastflow components. Water moves vertically to drains on the timescale of hours to days and laterally on the timescale of hours to months. Kronholm and Capel (2014) demonstrated that hydrograph separation methods, specifically the method of Wahl and Wahl (1995), can be used to describe slowflow and fastflow moving to a stream dominated by drainflow. The slowflow component describes water moving through the subsurface in areas far from the actual drains.

When subsurface drainage is present, the conceptual model of the continuum of two water sources to a stream must be expanded to include an additional end-member for landscapes with subsurface drainage (fig. 2B). All streams can be located within a conceptual triangle described by the three end-member sources of slowflow, fastflow, and drainflow. This explanation is a simplification for many streams but is a useful tool for assessing the contributions of various sources of water to a stream.
Streams in small watersheds are categorized by their characteristic flowpaths. Figure 3 shows rivers and streams in agricultural areas across the United States that are expected to have slowflow, fastflow, and drainflow as their characteristic flowpaths (corresponding to areas near the apices of the triangle in figure $2 B$ ), and areas with a mixture of flowpaths (areas away from the apices of the triangle in figure $2 B$ ). The conceptual map in figure 3 is based on an analysis of watershed properties, the likely locations of subsurface drainage, and an analysis of streamflow at gaged streams (see appendix 1 for more details). Although this map is conceptual and based on limited information, it provides a basis for understanding which flowpaths are likely to be important in various areas of the Nation. Caution should be used with such a map because all flowpaths are affected by local conditions, which are unavailable on national-scale maps. Even the flowpaths leaving adjacent fields could be quite different due to variabilities in topography, soils, land management, and the presence of subsurface drainage.

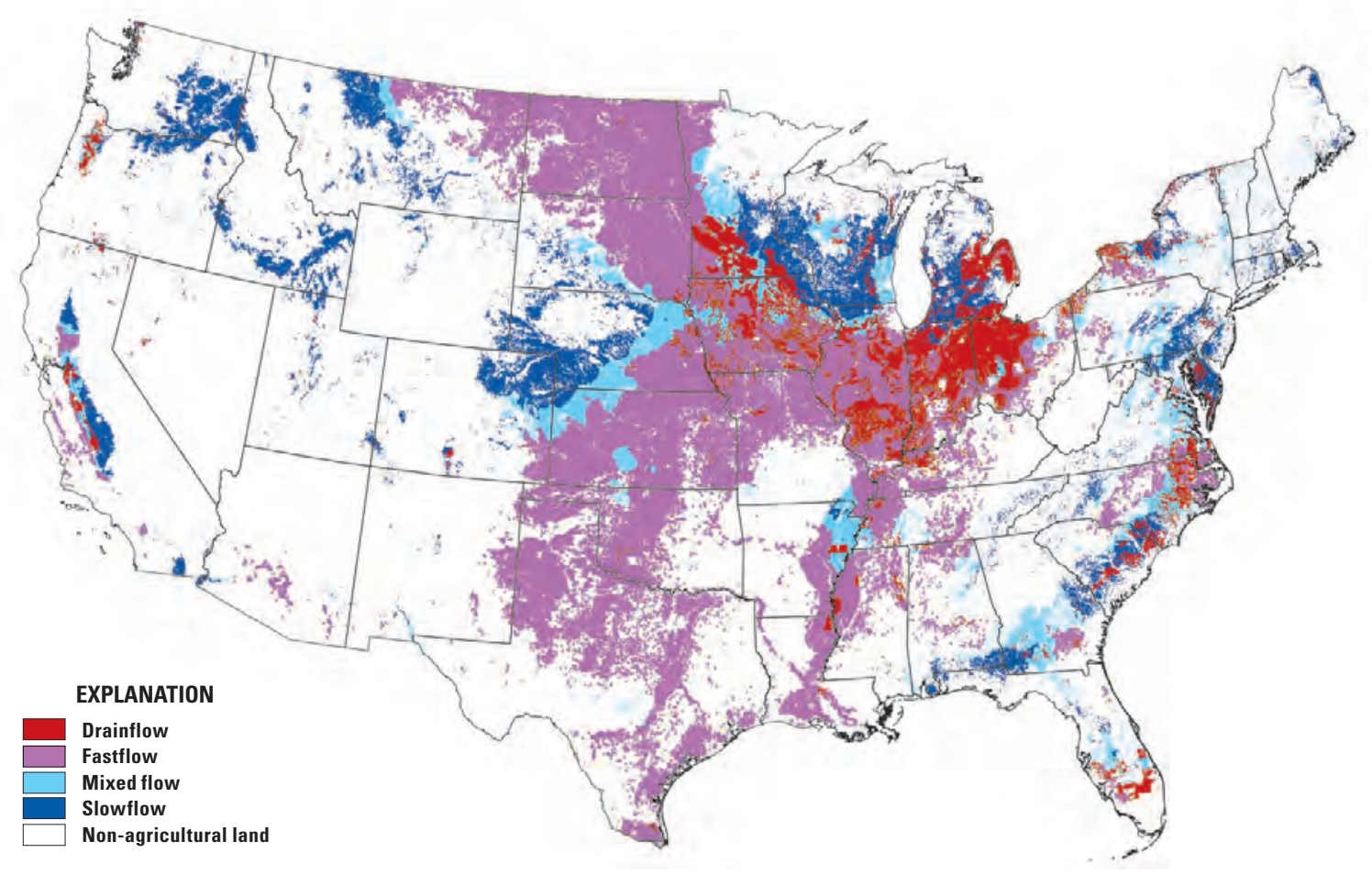

Figure 3. A conceptual map of the conterminous United States showing areas of crop agriculture expected to have slowflow, fastflow, and drainflow as their characteristic flowpaths. Corresponds to areas near the apices of the triangle (fig. $2 B$ ) and areas with mixed of flowpaths (areas away from the apices of the triangle in figure $2 B$ ). This map is conceptual and based on limited information. Caution should be used with such a map because all flowpaths are affected by local conditions unavailable on national-scale maps. See appendix 1 for details on the assumptions and data for this map. 


\section{Examples of Three Streams with Different Characteristic Flowpaths}

Three small watersheds with different hydrologic settings provide examples of streams receiving different annual distributions of slowflow, fastflow, and drainflow (fig. 2B). A 1-year portion of their outlet streamflow hydrographs and precipitation records are shown in figure 4 for comparing contributions from fastflow, slowflow, and drainflow. In these examples, the hydrograph was separated into baseflow and non-baseflow components (surrogates for slowflow and fastflow) by the method of Eckhardt (2005) using the approximation of Collischonn and Fan (2013) for one of the fitting parameters.

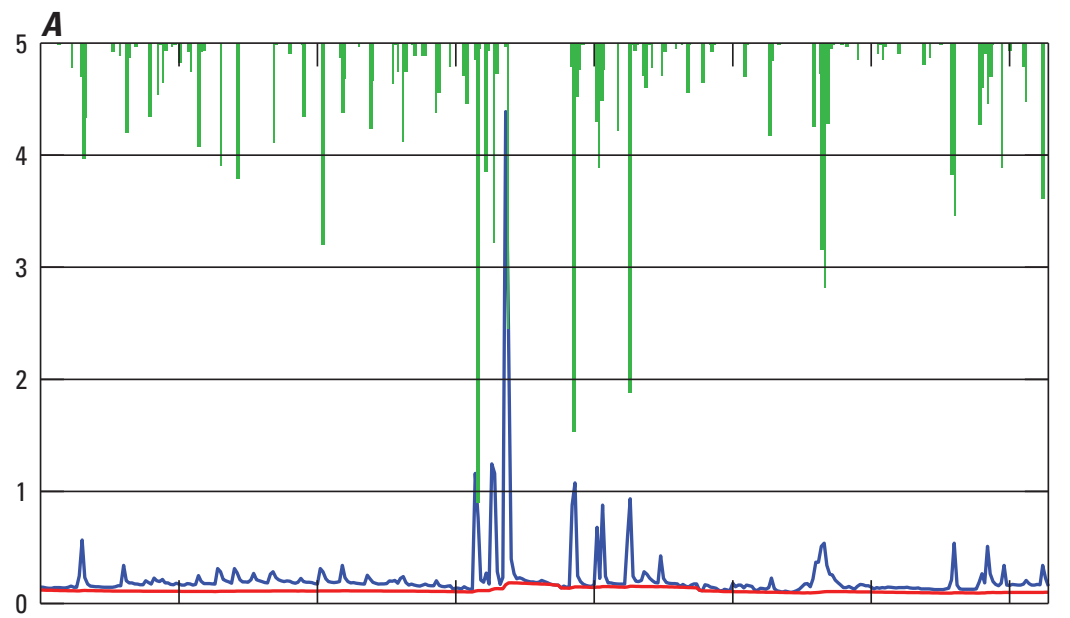

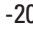

$-40$

$-60$

$-80$

$-100$

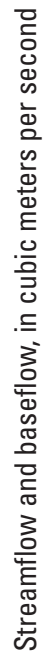

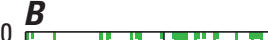

B 
The stream in Maryland (Chesterville Branch, USGS (U.S. Geological Survey) Station 01493112, median streamflow $0.17 \mathrm{~m}^{3} / \mathrm{sec}$ (2013), watershed area: $15.9 \mathrm{~km}^{2}$ (fig. 4A)) has substantial baseflow throughout the year with increased streamflow within a day of rainfall. This stream had a mean daily baseflow index (BFI) of $0.69( \pm 0.18)$, with about 45 percent of total annual streamflow from baseflow. The median transit time for water in the shallow aquifer draining to Chesterville Branch is about 28 years (Sanford and Pope, 2013). In this slowflow watershed, fastflow processes contribute to the stream, as indicated by peaks in streamflow after rainfall. The water represented by this hydrograph is a combination of recent rainwater and older groundwater being discharged into the stream. Figure $5 A$ shows the portions of the watershed estimated to contribute slowflow to the stream as a function of time (see appendix 2 for method details).

The stream in Kansas (Indian Creek, USGS Station 06893390, median streamflow $1.07 \mathrm{~m}^{3} / \mathrm{sec}$ (2013), watershed area: $166 \mathrm{~km}^{2}$ (fig. 4B)) is a fastflow-dominated urban stream not well-connected to shallow groundwater. The stream has a mean daily BFI of $0.62( \pm 0.26)$. Only about 33 percent of total annual streamflow is from baseflow. Much of the water moving through the stream comes from fast flowpaths that are largely overland flow. Because this is an urban stream, engineered flowpaths to the stream could also have slower transit times and appear in the hydrograph as baseflow from groundwater. Streamflow always returned to a stable background level within a 2- to 3-day period after peak streamflow. Figure $5 B$ shows the portions of the watershed estimated to contribute to streamflow, as a function of time, after a rain event. The hydrologic transit times of peak fastflow ranges from 0 to 12 hours. Not all areas of the watershed contribute water to the stream after a rain event. Some areas of the watershed are too distant from the stream for rainwater to move to the stream. This water is lost to infiltration or evapotranspiration before reaching the stream (fig. 5B).

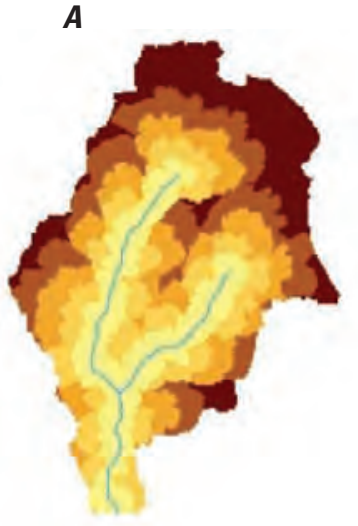

EXPLANATION

Transit time to stream, in years $0-7$

$8-16$

$17-26$

$27-36$

$37-74$
B

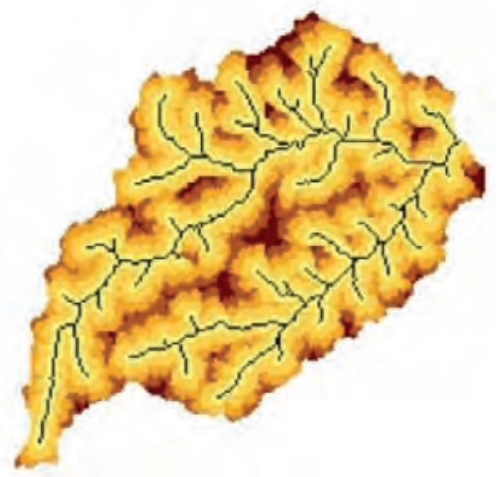

\section{EXPLANATION}

Transit time to stream, in hours

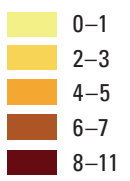

C

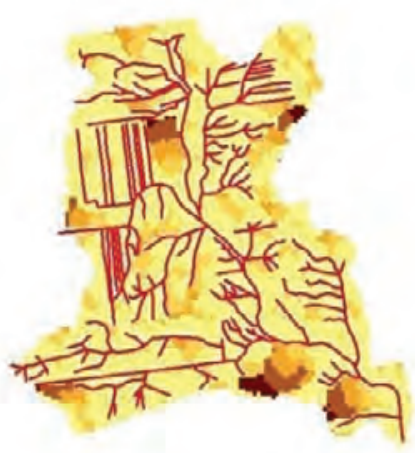

EXPLANATION

Transit time to stream, in hours

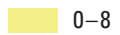

9-16

17-24

25-32

- 33-48

Figure 5. Estimated hydrologic transit times for the characteristic flowpath for the three example streams based on the conceptual framework.

A. Chesterville Branch, Maryland, with a slowflow characteristic flowpath.

B. Indian Creek, Kansas, with a fastflow characteristic flowpath.

C. Leary-Weber Ditch, Indiana, with a drainflow characteristic flowpath.
All three streams have some component of fastflow. See appendix 2 for the details of how the conceptual framework was used to develop the estimates of hydrologic transit times. 
The third example is a small stream in Indiana whose watershed has an extensive subsurface drainage network (Leary-Weber Ditch, USGS Station 06893390, median streamflow $0.018 \mathrm{~m}^{3} / \mathrm{sec}$ (2013), watershed area: $7.2 \mathrm{~km}^{2}$, (fig. 4C)). The stream is not well-connected to shallow groundwater and berms are present along much of its length, so opportunities for overland flow to the stream are limited. Streamflow appearing as baseflow in the hydrograph is not from groundwater but rather from slow drainflow through a subsurface network of drains. On the basis of the hydrograph separation method, Leary-Weber Ditch has a mean daily BFI of $0.62( \pm 0.26)$, but only about 17 percent of total annual streamflow is quantified as baseflow. In response to rainfall, streamflow increases because of fastflow moving through the subsurface drain network from areas on the landscape near the subsurface drains (fig. 5C), plus a small amount of overland flow. Many hydrograph peaks have a recession tail that lasts from 3 to 5 days after peak streamflow, suggesting a component of slower flow from areas in the landscape farther from a subsurface drain. In some instances, hydrologic transit times extend to weeks. Figure $5 C$ shows the portions of the watershed estimated to contribute to streamflow, as a function of time, after rainfall.

\section{Chemical Behavior}

More than 7,000 chemicals are associated with plant and animal agriculture (Velkoverh and others, 2016). Each chemical behaves uniquely in the environment, but all are subject to common physical, chemical, and biological processes. Sorptive processes determine the extent to which a chemical is associated with sediment and water. Transport processes move chemicals and sediment from one location to another; for example, from the soil surface, through the layers of soil to a subsurface drain, into an agricultural ditch, then to a major river, and, ultimately, to the ocean. Finally, chemical reactions transform the structure of the original chemical to produce new chemicals (transformation products). These processes, taken together, can be used to understand and identify the environmental behavior and transport of a chemical.

\section{Chemical Sorptivity and Transport}

Chemical sorptivity describes the extent to which a chemical is associated with sediment. The hydrologic conditions that allow a chemical to be transported are strongly correlated to the extent of association with sediment. The removal of a chemical, by settling and filtration processes in soil and vegetation, is strongly correlated to its extent of association with sediment.
Although sediment-both eroded soil and suspended sediment-is not a chemical as such, it is herein treated as a chemical. On the sorption continuum, sediment particles are the end-member of sediment-associated constituents. The actual sediment and chemicals associated with sediment are mobilized by the same hydrologic forces.

The extent to which a chemical is associated with water or sediment is determined by the chemical's characteristics along with the characteristics and relative volumes of water and sediment. For any specific chemical, its sorptive behavior is similar and predictable in similar hydrologic environments. All chemicals fall along a continuum between 100 percent associated with water and 100 percent associated with sediment. Some chemicals fall near one end of the continuum (table 2), but many chemicals have a substantial fraction in both the water-associated and sediment-associated phases and fall all along the continuum. For this discussion, the movement of chemicals into the air is ignored.

The linear continuum of sorptivity, combined with the linear hydrologic continuum defined by slowflow and fastflow end-members of water flowpaths to the stream, yields a conceptual space in the shape of a rectangle (fig. 2C). In cases where a watershed contains subsurface drainage, the continuum of sorptivity can be combined with the space defined by slowflow, fastflow, and drainflow end-members, yielding a conceptual space shaped like a triangular prism (fig. 2D). Any chemical or sediment in any stream can be located within these conceptual spaces. All water travels to the stream by a combination of slowflow, fastflow, and (or) drainflow processes. All chemicals are distributed within the end-members of the sorptivity continuum. Within this conceptual space, chemicals with the same distribution between water and sediment (fig. $2 D$, gray, offset triangle) can be located within the hydrologic space of any stream (fig. 2D, small blue square). Chemicals proximate to each other within this space (meaning they possess similar chemical sorptivity and a similar hydrologic setting) would be expected to behave similarly. The combined expectations, based on the sorptivity of chemicals and the transit times of water moving through various flowpaths, allow for behavioral generalizations among chemicals and hydrologic settings.

\section{Chemical Transformation}

Chemical reactions result in the loss of the original chemical and the production of one or more new chemicals. Chemical transformations are induced by external forces (energy from the environment) acting on the chemical, including biological (plants, animals, or microorganisms), chemical (reactions with other chemicals), and physical (sunlight and heat) factors. For carbon-based (organic) chemicals, transformation occurs as a one-way path from the 
Table 2. Selected examples of water-associated and sediment-associated agricultural chemicals.

[Water-associated chemicals: Estimated that greater than 75 percent is associated with water (see appendix 3). Sediment-associated chemicals and sand: Estimated that greater than 80 percent is associated with sediment (see appendix 3). Although sediment is not a chemical, it is grouped here because sediment undergoes the same transport processes as sediment-associated chemicals.]

\section{Water-associated chemicals}

Nitrate, chloride, sulfate

Potassium

Alachlor, atrazine, metolachlor

Deethyl atrazine, metolachlor ethanesulfonic acid, metolachlor oxinilic acid

Azinphos-methyl, carbaryl, malathion, phorate

Iprodione

$17 \alpha$-ethinylestradiol, testosterone

Sulfachloropyridizine, tylosin

\section{Sediment-associated chemicals}

Sand

Total phosphorus, orthophosphate

DDE, DDT

Arsenic (III and V), lead (II), selenium (VI)

original chemical to its transformation products. For chemicals with other core elements, such as nitrogen, phosphorus, boron, and arsenic, the original chemical form is changed in a reaction, but the elements are preserved in different chemical forms. Elements never disappear; they merely change chemical form.

The rate of loss of the original chemical is traditionally described by first-order (or pseudo first-order) kinetics and depends on a rate coefficient and the concentration of the chemical. The time it takes for one-half of a chemical's mass to be lost is called its half-life. (See table A3-2 in appendix 3 for the half-lives of selected agricultural chemicals.) A chemical's half-life is environment specific; it depends on the physical, chemical, and biological conditions of the environment. Regardless of chemical type, after seven halflives, $>99$ percent of the original chemical has been lost. When considered in the same way as chemicals, particles of sediment have extremely long half-lives, such that their environmental half-life should be regarded as infinite.

Specific chemicals have a narrow and predictable range of half-lives in a given environmental compartment (such as soil, groundwater, and similar types; Mackay and others, 2006). The half-life of a chemical is important for setting expectations of water-quality improvements resulting from changes in agricultural activities that alter the hydrologic transit times in fields and watersheds. For example (fig. 6), if a chemical has a half-life of 10 days, it would not be a water-quality concern in slowflow settings with a hydrologic transit time of $>70$ days, since $>99$ percent would be lost in 70 days. However, the half-life could be a concern in fastflow environments with shorter hydrologic transit times.

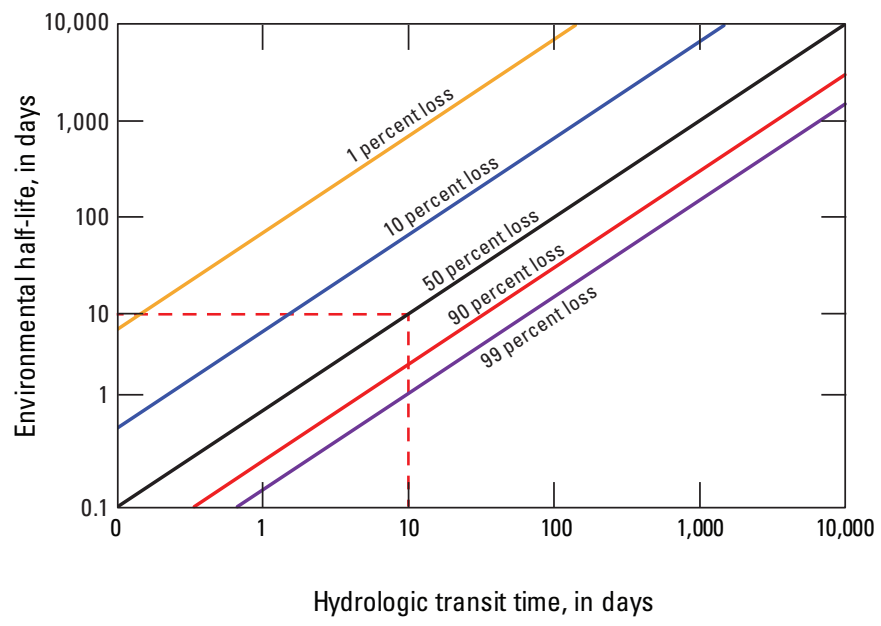

Figure 6. Lines of percent chemical-loss as a function of hydrologic transit time and chemical half-life. The hydrologic transit time is the period between the input of input of water at the land surface and its appearance in the stream. The dashed red lines show that 50 percent of a chemical with a half-life of 10 days would be lost in a flowpath (meaning a stream, wetland, or shallow groundwater) with a hydrologic transit time of 10 days. 


\section{Combining Sorptivity, Transformation, and Hydrologic Transit Times}

The potential exists for chemicals and their transformation products to remain in the environment and become legacy chemicals. In surface water, legacy chemicals are long-lived chemicals that bind strongly to sediment and accumulate in soil, stream-bottom sediments, and in the tissues of living organisms; they can be identified through their chemical properties and an understanding of the hydrologic system (Meals and others, 2010; Puckett and others, 2011). The degree of sorption and environmental half-life can provide insights into which chemicals might be water-quality concerns in various hydrologic environments (fig. 7). These chemicals are indicated in the upper-left portion of figure 7. Sediment from eroded soil and stream banks that accumulates in stream channels and streambeds are also a legacy concern and are indicated in the extreme upper-left corner of figure 7.

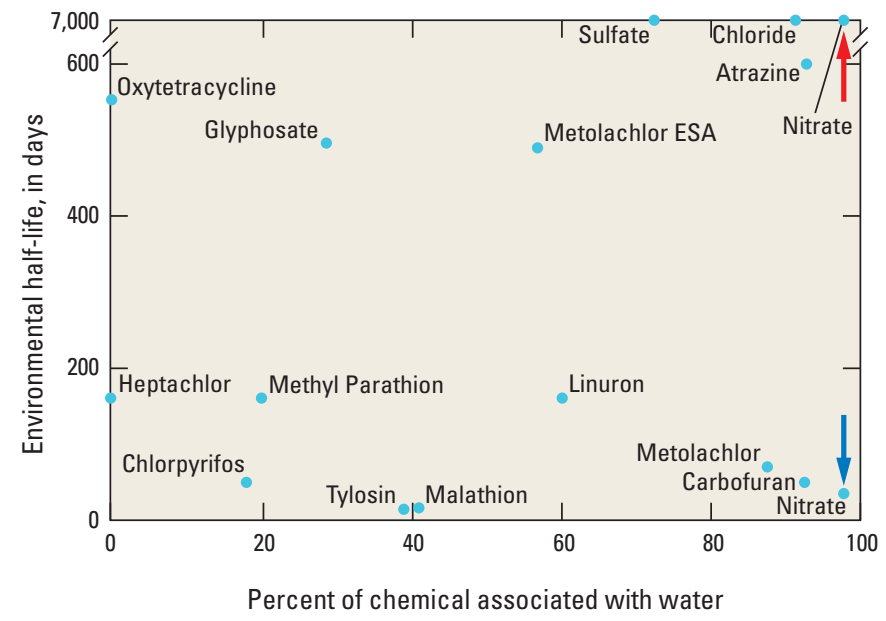

Figure 7. Environmental half-life and percentage of various agricultural chemicals in water. Legacy chemicals, those with long environmental half-lives, typically found in surface water and largely associated with sediment, are grouped on the upper-left side of the graph. Legacy chemicals typically found in groundwater are largely associated with water and are grouped on the upper-right side of the graph. Nitrate is readily removed in subsurface environments with no or low dissolved oxygen (reduced conditions, as indicated by the blue arrow) but has a long half-life in subsurface environments with higher dissolved-oxygen concentrations (oxic conditions, as indicated by the red arrow).
Legacy chemicals in groundwater are long-lived, water-associated compounds that move with water through the groundwater system. These chemicals are located in the upper-right portion of figure 7. Nitrate can have either a long or short half-life, depending on the concentration of dissolved oxygen. In environments containing dissolved oxygen-oxic conditions - nitrate has a slow rate of reaction. Therefore, nitrate persists as a legacy chemical.

\section{Field and Model Observations of Chemicals and Sediment in Relation to Agricultural Activities}

Trapping and conservation tillage are agricultural management practices (table 3) designed primarily to minimize soil erosion and the loss of eroded soil from a field (Reeder and Westermann, 2006; Baker and others, 2006a; additional references in appendix 4). These practices have the added benefit of protecting water quality from sediment and sediment-associated chemicals. Trapping and conservation tillage practices are effective because they dissipate the erosive energy of flowing runoff water by reducing its velocity, resulting in a decrease in the volume of runoff and an increase in the volume of infiltration. These effects can be seen in figure 8 , which shows the results of the Water Erosion Prediction Project (WEPP) (Flanagan and others, 1995), through the increase in infiltration and decrease in sediment yield for a number of trapping and conservation tillage practices, compared to corn planted with conventional tillage (Roth and Capel, 2012a). The effect of trapping and conservation tillage practices on the movement of soil is represented and quantified in deterministic models such as WEPP and the Kinematic Runoff and Erosion model (KINEROS) (Woolhiser and others, 1990). A tremendous volume of scientific and practical literature exists on the implementation of these practices for cropped fields with a wide range of soils, crops, topography, and rainfall or irrigation conditions (U.S. Department of Agriculture, Natural Resources Conservation Service, 2014a).

Compared with sediment itself, fewer studies have been done on the effectiveness of trapping and conservation tillage practices on sediment-associated chemicals (table 2). In a review of the literature, Arora and others (2010) estimated that about 70 percent of sediment-associated pesticides were retained within a vegetative buffer strip. 
Table 3. Selected examples of agricultural management practices and other agricultural activities used to help minimize chemical and sediment loss to protect and improve water quality.

\section{Trapping practices \\ Terraces \\ Grassed waterways \\ Buffer/filter strips \\ Brims at edge of stream \\ Cover crops \\ Tillage practices \\ Conservation tillage \\ No-till tillage \\ Contoured plowing \\ Drainage practices}

Controlled subsurface drainage

Biofilters on subsurface drains

Removal of subsurface drains

Removal of surface inlets to subsurface drains

\section{Irrigation practices}

Reduced volume and energy of irrigation water

\section{Chemical use practices}

Reduction in chemical use

Use of chemicals with short environmental half-lives

\section{Set-aside land for conservation}

Conservation reserve programs (Federal and State; for example, U.S. Department of Agriculture's

Conservation Reserve Program (USDA CRP))

Constructed wetlands

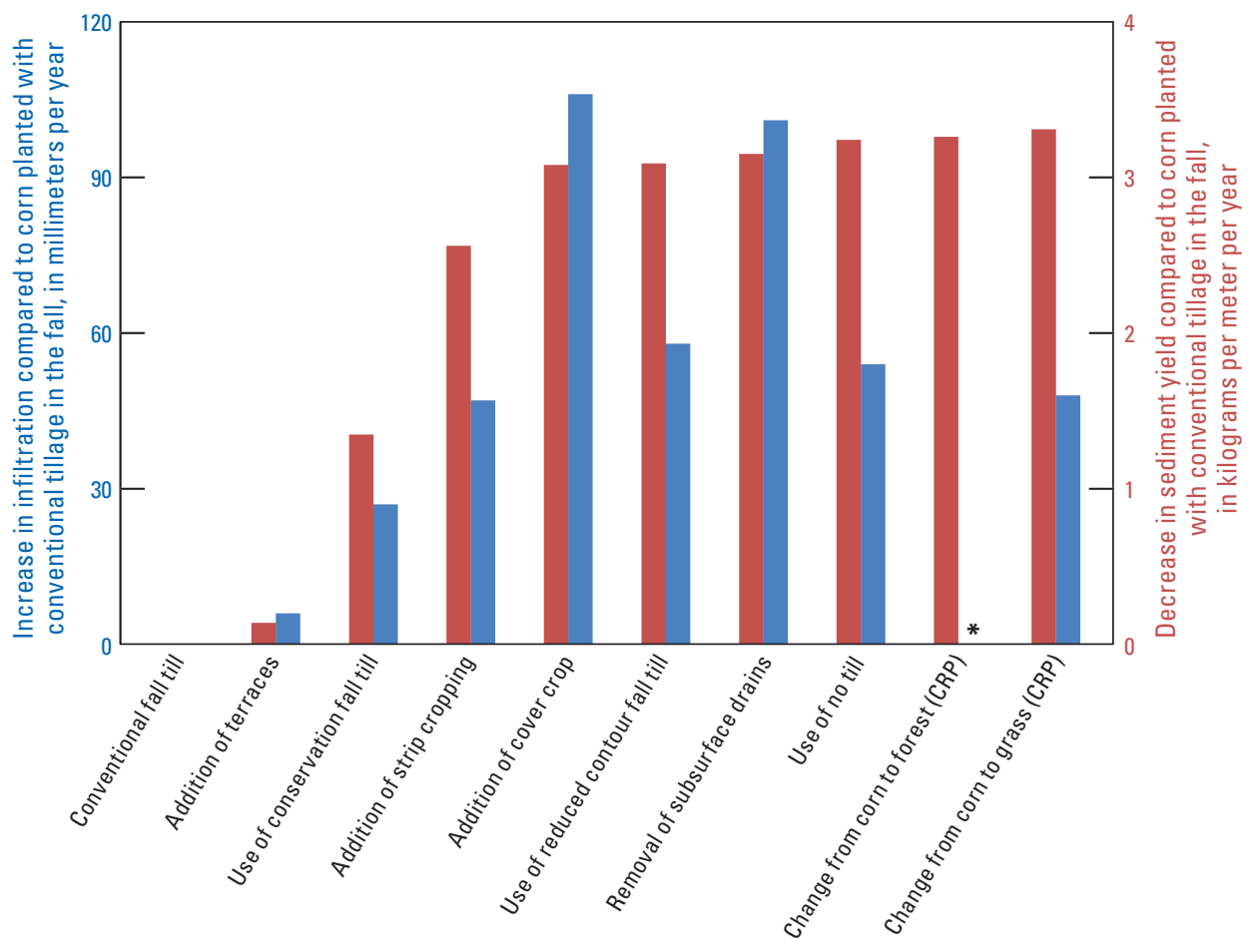

Figure 8. Estimated increases in infiltration (millimeters per year $(\mathrm{mm} / \mathrm{yr})$; blue bar) and decreases in sediment yield (kilograms per meter per year $(\mathrm{kg} / \mathrm{m} / \mathrm{yr})$; red bar) alongside a change in an agricultural management practice based on the results of the Water Erosion Prediction Project (WEPP) model. The basis of the comparison is corn planted with conventional tillage on loam soil with a 3 percent slope. One management practice was changed for each comparison. Rye was the cover crop. The results are the averages for 60 years of modeling for weather conditions similar to Greenfield, Indiana $(1,088 \mathrm{~mm} / \mathrm{yr}$ average precipitation). The asterisk $(*)$ denotes a decrease in infiltration. Both runoff and infiltration decreased because of increased transpiration from trees (data from Roth and Capel, 2012a). Conservation Reserve Program data are indicated by the abbreviation CRP. 
Based on observations in the western portion of the Midwest Corn Belt, Wortmann (2011) suggested that about 50 percent of total phosphorus is removed by a vegetative buffer strip, and about 30 percent can be removed both by contour farming (without terraces) and by the use of terraces. Trapping and conservation tillage practices can be effective at removing, to some extent, sediment-associated chemicals and protecting and improving the water quality of a stream.

Trapping and conservation tillage practices are not as effective for water-associated chemicals, nor should they be expected to be. Many of the trapping and conservation tillage practices are designed to slow flowing water and allow sediment particles to settle, but these practices do not stop the water from reaching the stream. Water-associated chemicals do not settle; they stay in solution as the water moves across or through the landscape where the practices are implemented. Some fraction of the water-associated chemicals are retained within treated areas due to infiltration, uptake by the vegetation, and other processes (Wortmann, 2013b). Wortmann (2011) suggested that about 25 percent of soluble phosphorus and 35 percent of total nitrogen can be removed by a vegetative buffer strip, whereas soluble phosphorus and total nitrogen can be reduced about 20 percent by contour farming (without terraces) and 10 percent by terraces with tile outlets. However, trapping and conservation tillage practices increase infiltration (fig. 8) and can enhance the movement of water-associated chemicals (table 2) through the soil layers to subsurface drains and groundwater. These water-associated chemicals are frequently observed in groundwater and subsurface drain discharge beneath agricultural land (Gilliom and others, 2006; Blann and others, 2009; Dubrovsky, and others, 2010; Zebarth and others, 2015a). Trapping and tillage practices have essentially no effect on water-associated chemicals moving via drainflow and slowflow. Once the water-associated chemicals are in the subsurface, they are no longer influenced by activities at the surface and only natural transformation processes can decrease their concentrations until they are eventually discharged to a stream. Many other agricultural activities can also affect the quality of water in a stream.

Low-volume, low-intensity irrigation (as with a drip, lowflow sprinkler) can cause less erosion than other types of irrigation, decrease the runoff of sediment and chemicals to streams, and decrease the infiltration of water-associated chemicals into the subsurface (Eisenhauer and others, 2006). As an example, the change from flood irrigation to drip irrigation in central Washington substantially decreased stream loads of suspended sediment and total phosphorus (Fuhrer and others, 2004).

Subsurface drains provide a conduit for water-associated chemicals to move to the stream quickly. Blann and others (2009) have concluded that subsurface drains are important to the movement of nitrogen and herbicides to streams. Streams in watersheds with substantial subsurface drainage ( $>5$ percent of area) usually have higher stream-nitrate concentrations and higher nitrate loads as a percent of use than streams in agricultural watersheds with little or no drainage (Dubrovsky and others, 2010). Roth (2010) showed that surface inlets into subsurface drains, which drain temporary ponds in cropped fields, provide a direct pathway for both water- and sediment-associated chemicals and sediment to reach streams (see appendix 5).

Controlled drainage (Lowrance and others, 2006) and biofilters (Schipper, 2010; Andrus and others, 2014) are used to protect and improve water quality. Controlled drainage retains water in the subsurface for a set period before releasing it from the drain to allow more time for chemical transformation, such as denitrification, to occur. Biofilterszones of wood chips or other carbon sources inserted into subsurface drains - provide a highly reactive environment for transforming nitrogen and capturing phosphorus from drain water.

Constructed wetlands mimic, and compensate for the loss of, natural wetlands (Lowrance and others, 2006). Constructed wetlands intercept and remove sediment and chemicals from runoff and drainage water before the water reaches a stream. These wetlands also provide flood control by reducing the velocity of water and storing it on the landscape.

The most effective way to protect water quality from agricultural chemicals is to reduce or eliminate the use of the chemicals. The less chemical applied, the less chemical there is to move into the stream. This pattern has been demonstrated with nitrogen and various water-associated herbicides; after their use was substantially decreased or discontinued, their concentrations in the stream quickly decreased (as demonstrated with cyanazine and alachlor; Sullivan and others, 2009; Kalkhoff and others, 2012). In many cases, the discontinued chemicals were no longer observed in streams. On the other hand, new water-associated chemicals can be observed in streams soon after introduction. For example, the herbicide acetochlor was present in streams within the first year of use (Capel and others, 1995). Sediment-associated chemicals behave differently; they do not always show a direct and immediate correlation between a change in use and an in-stream concentration. Sharpley and others (2013) have shown this outcome for phosphorus in many diverse agricultural settings. Nowell and others (1999) revealed that after dichlorodiphenyltrichloroethane (DDT) and other organochlorine insecticides were restricted for agricultural use, the concentration initially decreased in the stream (as evidenced by the concentration in fish), but then reached a concentration plateau because the chemicals were continuously supplied to the stream from their storage in bed sediments and soils.

Land being removed from production and set aside for conservation is another effective agricultural activity for improving water quality. This activity is especially effective in areas of the landscape that disproportionately contribute chemicals and sediment to the stream. Examples include areas adjacent to water bodies that are susceptible to erosion and topographic depressions that are drained with vertical inlets (Roth and Capel, 2012b). Removing 
cropland from production, through programs such as the Department of Agriculture's Conservation Reserve Program (CRP) (U.S. Department of Agriculture, Natural Resources Conservation Service, 2014b), reduces or eliminates the use of agricultural chemicals. Streams that drain watersheds with a substantial area in the CRP have decreased concentrations of nitrogen and phosphorus and improved ecological health (Christensen and others, 2009). These streams show a decrease in suspended sediment caused by the continuous vegetative ground cover and development of a stable root network.

\section{Choice of Agricultural Activities in the Context of Hydrologic Setting and Chemical Behavior}

The U.S. Department of Agriculture, Natural Resources Conservation Service's Field Office Technical Guide (NRCS FOTG) categorizes the effectiveness of various conservation practices for a large number of settings and different types of chemicals as an aid to producers in each State (U.S. Department of Agriculture, 2015b). The NRCS FOTG identifies 11 effectiveness categories spanning the range of "significant increase in the problem" to "significant decrease in the problem." The U.S. Environmental Protection Agency (2003) has applied the information provided in the NRCS FOTG to the expected beneficial or detrimental effects on the quality of groundwater and surface water for many conservation practices for categories of chemicals (pesticides, nutrients, sediment, pathogens, and other constituents).

Understanding the connections between agricultural activities, water flowpaths, and the behavior of specific chemicals and sediment can be combined into a framework to guide policy and management decisions that reduce current, and prevent new, water-quality effects. This framework is built on a generalization of stream hydrology — water, whether from natural rainfall or irrigation, moves to a stream by a combination of slowflow, fastflow, and drainflow; where each flowpath is associated with a range of timescales. The framework generalizes the behavior of chemicals and sediment; all chemicals and sediment are distributed on a continuum between those completely associated with water and those completely associated with sediment. Additionally, individual chemicals are transformed in the environment with a known, expected rate of loss. Finally, each agricultural activity is assumed to have an expected effect on the movement of water and chemicals across the landscape. This framework is an oversimplification of a complex system, but it is useful for decision making and supported by observations in the field and quantified in models.

On the basis of this framework, two decision trees are suggested. These organizing tools allow users to anticipate better the effectiveness of changes in agricultural activities as a way to protect and improve the water quality of streams. These tools are not intended to be used on a site-specific basis. Detailed knowledge of the local environment, climate, and agricultural production is required for design decisions when implementing an agricultural activity at a particular location.

\section{Agricultural Activity Decision Tree as an Organizing Tool}

A decision tree with three basic questions can be used to determine the agricultural activities that could effectively protect and improve water quality in a stream affected by the movement of a specific chemical (or sediment) and also determine which activities could be counterproductive (fig. 9). The first question centers on the environmental behavior of the chemical of concern: Is the chemical primarily associated with sediment? The second question addresses the presence of permanent or semipermanent agricultural modifications to the landscape already in place: Is the water in question moving through subsurface drainage? The final question regards the nature of the hydrologic setting: Is the water in question moving through groundwater? The answers to these three questions can guide the selection of, and expectations for, the effectiveness of implementing a particular agricultural activity.

The decision tree in figure 9 organizes the decisionmaking process by hydrologic setting and chemical behavior, principally at the field and small catchment scales. In appendix 5, the agricultural activity decision tree is extended to include vertical inlets to subsurface drainage as a separate flowpath for water and chemicals (table 1).The decision tree in figure 9 considers water movement through all three endmember flowpaths (fastflow, slowflow, and drainflow) for nonreactive chemicals and sediment. The horizontal lines on the tree, between "yes" and "no," represent three continua. Starting at the top of the figure, these lines show the degree of association of the chemical with sediment (from 100 percent water-associated to 100 percent sediment-associated), the contribution of subsurface drains to total streamflow-which could be approximated by the density of subsurface drains, from 0 to a closely spaced, patterned drain network-and the contribution of groundwater to total streamflow (from 0 to 100 percent). The decision tree traces the two extremes for the continuum of sediment association by chemicals. Chemicals intermediate to these two extremes-chemicals with a substantial fraction in both water and sediment-associated phases-could follow multiple routes through the decision tree. Thus, it can be harder to establish expectations for the effectiveness of agricultural activities with these chemicals.

The degree of reactivity does not affect the use of the decision tree (fig. 9), except with reactive chemicals, which can disappear from the environment as they are transported via moving water when the hydrologic transit time is greater than the environmental half-life of the chemical (fig. 6). 


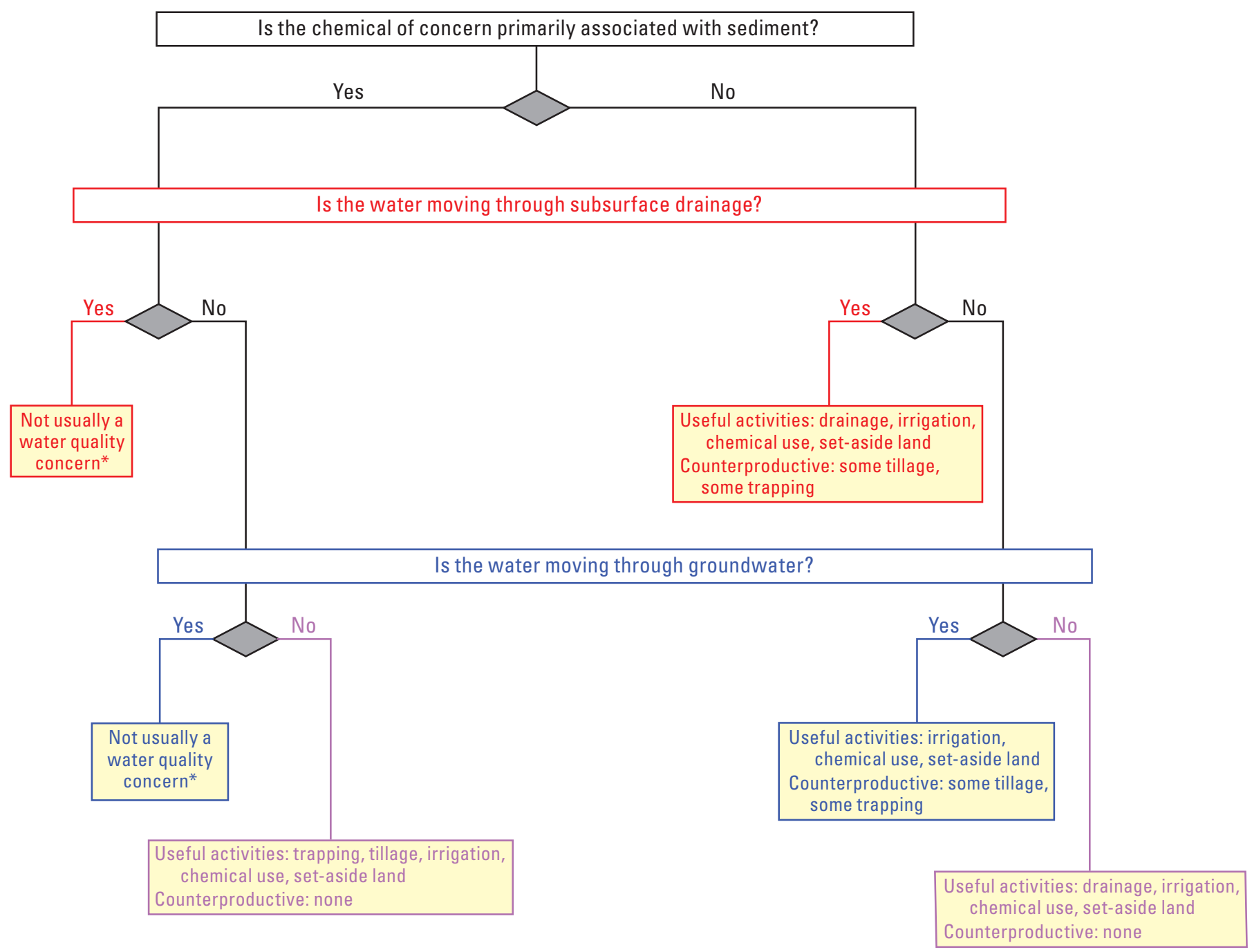

EXPLANATION

\section{Slowflow paths Fastflow paths \\ Drainflow paths}

Figure 9. A simple decision tree for determining which agricultural activities can protect and improve water quality in a local stream from the movement of a given chemical (or sediment) and which agricultural activities could be counterproductive. The groups of agricultural activities are listed in table 3 . The asterisk $\left({ }^{*}\right)$ denotes chemicals that do not often cause a water-quality concern from the portion of the water moving through subsurface flowpaths (such as moving through soil to groundwater or subsurface drains), but these chemicals can cause concern in the portion of water moving through surface flowpaths. 
For example, a chemical with a relatively short environmental half-life, such as nitrate in a reduced hydrologic environment (with no or low dissolved oxygen; fig. 7), is lost during its transport through the subsurface, which commonly has transit times on the order of months to decades. Conversely, a chemical with a long environmental half-life relative to the hydrologic transit time, such as the nitrate in an oxidizing hydrologic environment (with substantial dissolved oxygen present), does not appreciably change concentration during its transport through the subsurface, and oftentimes persists in the groundwater discharging into streams (Sanford and Pope, 2013).

An example application of the agricultural activity decision tree for a water-associated chemical in a stream where slowflow is an important component of streamflow follows. In figure 10, the thick, black line follows the behavior of a chemical strongly associated with water (for example, nitrate) in a hydrologic setting where there is minimal subsurface drainage, and groundwater is an important water flowpath to the stream (for example, Chesterville Branch, Maryland, fig. 4A). This area contains sandy soils and a shallow groundwater table. After decades of intensive crop and animal agriculture, much of the oxic groundwater in the area around the Chesterville Branch was contaminated with nitrate. The nitrate concentration in the stream is highest during the lowest streamflows.

On an annual basis, about half of the total streamflow is from groundwater. Following these decades of intensive agriculture in the Chesterville Branch watershed, a fraction of the applied nitrogen leached, as nitrate, through the sandy soils and into the groundwater (Sanford and Pope, 2013). In the recent past, and most likely long into the future, the groundwater discharging into the stream contributed high concentrations of nitrate. The median transit time for water in the shallow aquifer draining into the Chesterville Branch is about 28 years (Sanford and Pope, 2013).

Currently, there are no large-scale remediation strategies for nitrate removal in contaminated aquifers, although changes in agricultural activities on the landscape could be beneficial to the future water quality of the stream. Useful strategies could include decreasing the application of nitrogen to the landscape and decreasing the volume of recharging water that could be affected by reducing irrigation. Nitrogen inputs could be decreased by reducing the application rate and (or) removing farmland from production. Most trapping and tillage practices designed to reduce soil erosion can be counterproductive to nitrogen removal because they increase recharge and can increase the movement of nitrate into groundwater. Cover crops could effectively store nitrogen in the plants and soil, thereby delaying leaching, but the stored nitrogen has the potential to eventually leach into groundwater. One long-term advantage of cover crops is that they can store nitrogen in the soil until it is transformed in gaseous molecular nitrogen (denitrification), which can then move into the atmosphere and leave the watershed. In slowflow areas, such as the Chesterville Branch watershed, it can take years for a chemical like nitrate to move from the land into the groundwater and ultimately into the stream. Groundwater nitrate currently in this stream represents nitrates applied decades ago. Thus, the benefits of contemporary conservation actions may not be realized in this stream for several decades.

An example application of the agricultural activity decision tree for sediment in a stream where fastflow results from excess irrigation is given in figure 11. The thick, black line follows the behavior of sediment in a hydrologic setting where fast flowpaths are an important component of total streamflow, at least for part of the year. As an example, fastflow to Granger Drain in central Washington occurs when excess irrigation water is present on the landscape (Kronholm and Capel, 2014). Irrigation water is relatively abundant as snowmelt from the Cascade Mountains. Excess irrigation runoff transports large amounts of sediment, along with agricultural chemicals associated with sediment (for example, total phosphorus and DDT; Fuhrer and others, 2004). Sediment (as eroded soil) is transported across the land surface to the stream and does not move into the subsurface.

Since the early days of farming, the streams and rivers of central Washington have been affected by sediment in irrigation runoff. Much of the sediment came from fields receiving furrow irrigation, which is an inefficient method of irrigation that can cause heavy soil erosion. In the late 1990s, irrigation practices moved rapidly away from furrow irrigation to sprinkler and drip methods, due in part to the availability of low-interest loans to farmers. This widespread change in agricultural activities resulted in dramatic improvements in water quality: sediment loads were reduced by more than 90 percent in some locations. The reduction of irrigation water, combined with more efficient irrigation methods, were effective choices for controlling sediment in runoff. More recently, other sediment control methods, such as the use of polyacrylamide (PAM) and even more efficient methods of irrigation, have been used (Fuhrer and others, 2004). In fastflow environments, as with the excess irrigation water in Granger Drain, the benefits of conservation actions, specifically improvement in stream water quality, can occur quickly. In this stream, turbidity and suspended sediment, total phosphorus, and DDT concentrations decreased substantially within several years of the changes in irrigation practices. 


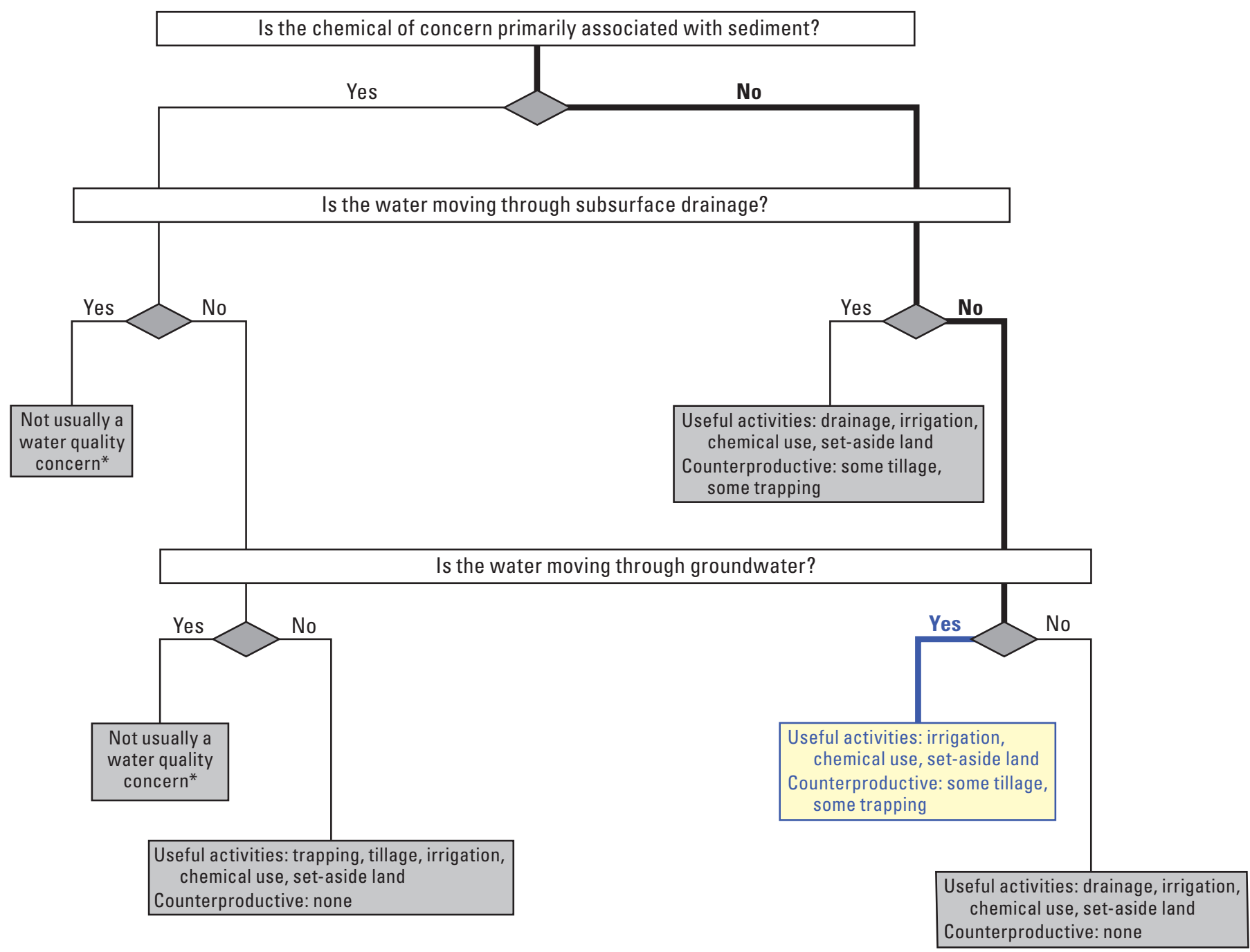

\section{EXPLANATION}

\section{Slowflow paths}

Figure 10. A simple decision tree for determining the agricultural activities that could protect and improve water quality with regard to a water-associated chemical (like nitrate) in a stream where slow flowpaths (groundwater) are an important component of total streamflow. The groups of agricultural activities are listed in table 3. 


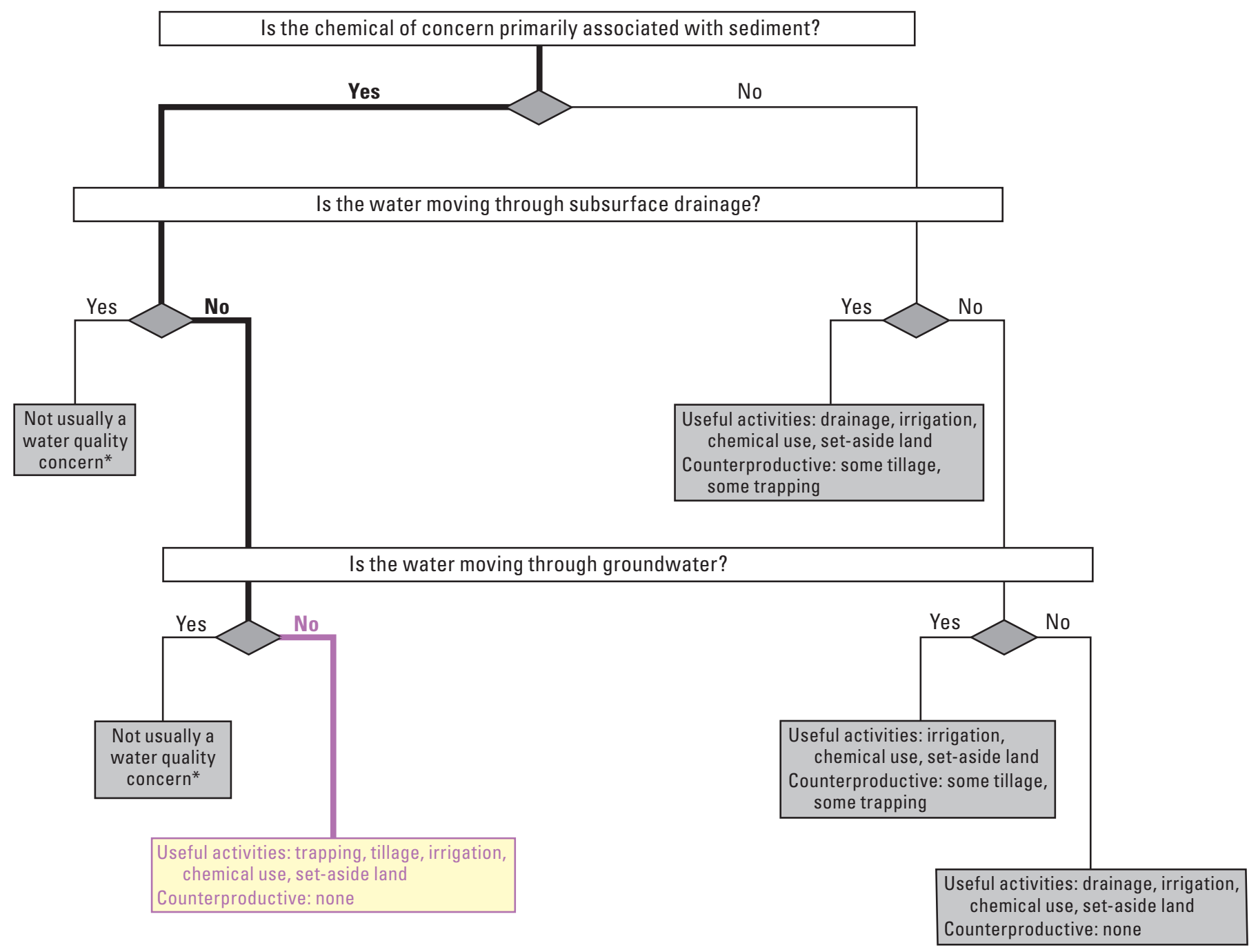

\section{EXPLANATION}

Fastflow paths

Figure 11. A simple decision tree for determining the agricultural activities that could protect and improve water quality with regard to sediment in streams where fast flowpaths (surface runoff) are an important component of total streamflow, at least for part of the year. The groups of agricultural activities are listed in table 3.

\section{Chemical Fate Accounting Tree}

The companion to the agricultural activity decision tree (fig. 9) is a chemical-fate accounting tree (fig. 12) that considers the long-term fate of a chemical or sediment removed by a trapping or conservation tillage practice (table 3). The purpose of many of these practices is to protect and improve water quality by removing chemicals or sediment. The removed chemicals and sediment do not instantaneously disappear from the environment; they are stored until they are transformed into other chemicals or remobilized. Every individual chemical is unique regarding its reactivity and fate.

In figure 12, three types of constituents-sediment, elements, and organic chemicals_-are tracked through the chemical-fate accounting tree to illustrate the effect of a trapping or conservation tillage practice. Sediment is nonreactive and simply trapped and stored within the trapping or conservation tillage practice area. The sediment could remain within the practice area indefinitely or be remobilized by surface runoff from a storm or by irrigation runoff.

Elements (for example, nitrogen, phosphorus, boron, or arsenic) trapped by a given management practice can undergo arious chemical and biological processes. Although an element cannot be transformed into a different element, its chemical form can be changed; for example, the nitrogen in ammonia can be transformed into nitrate. Furthermore, the element could be changed into a chemical form that readily associates with water and then be transported to the subsurface via infiltration or to a stream via runoff. 


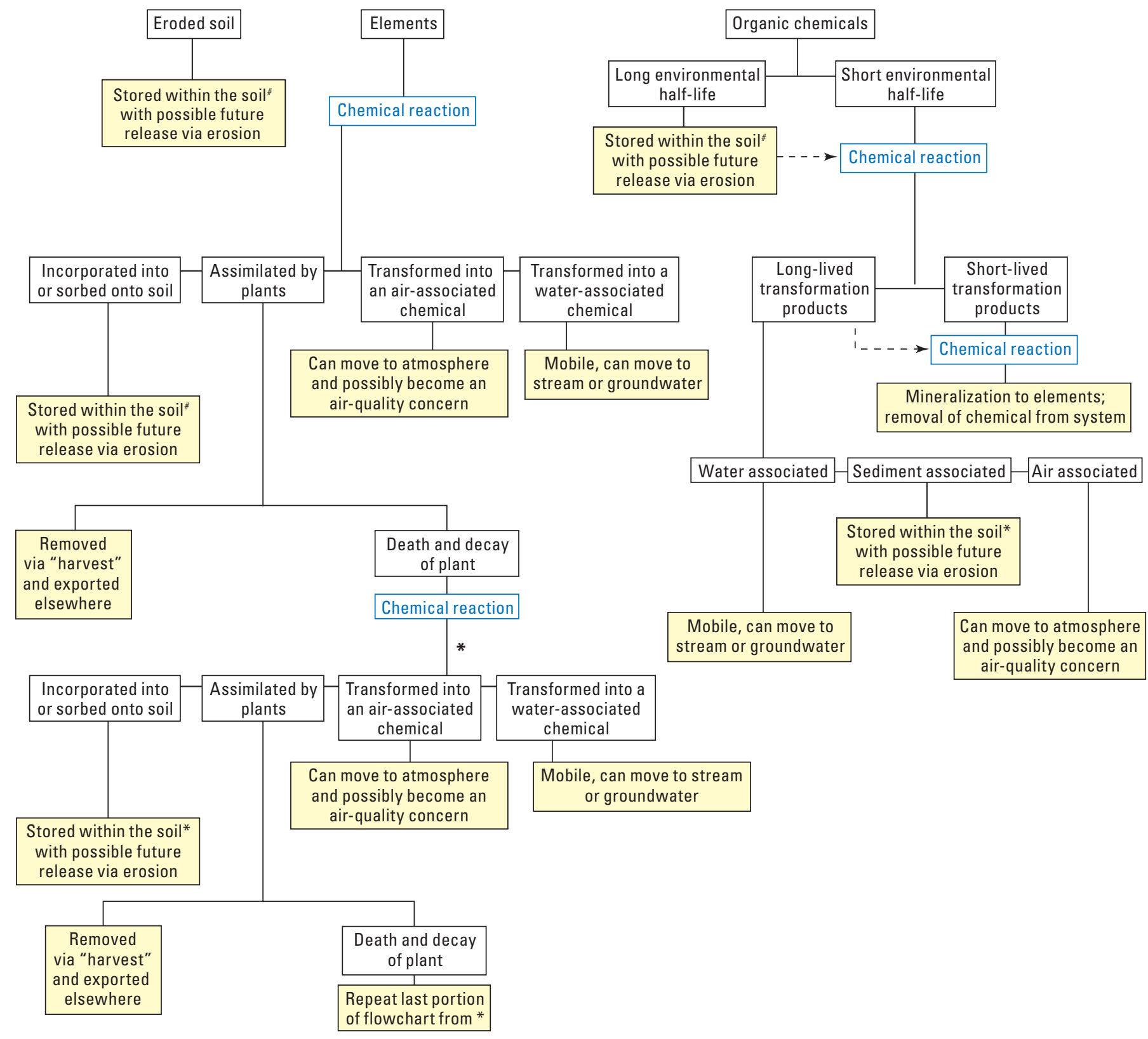

Figure 12. A chemical fate accounting tree for eroded soil (sediment), elements, and organic chemicals sequestered from transport via moving water by a trapping practice or conservation tillage (table 3). The soil designated with the pound sign (\#) denotes the surface soil within the trapping practice or field. The asterisk $\left(^{*}\right)$ denotes that this branch of the tree can be repeated as many times as needed. 
Nitrate is an example of a water-associated form of nitrogen transported readily by water. The element could, further still, be changed into a volatile form and move into the atmosphere (for example, as molecular nitrogen or nitrous oxide). This volatile fraction of nitrogen is thereby lost from the agricultural area. The possibility also exists for the element to be absorbed by growing plants and incorporated into the vegetation biomass. If all or part of the plant is removed or harvested, then the element is lost. If it is not removed, the plant decays and returns the element to the soil to repeat another cycle of transformations. Finally, the element can be incorporated into the soil (sediment) particles (for example, as nitrogen in soil organic matter). In this case, the element can be transported with the sediment particle, should it become remobilized.

Organic chemicals transform into other compounds in either a linear or branched, noncyclic manner. Most synthetic organic compounds (for example, herbicides, insecticides, and antibiotics) eventually return to their elemental building blocks (for example, carbon, oxygen, nitrogen, chloride). The fate of an organic chemical, within the trapping or conservation-tillage agricultural management practice, is principally determined by its environmental half-life. Those chemicals with long environmental half-lives are simply stored and may eventually be remobilized. Chemicals with shorter environmental half-lives are transformed into new chemicals. Each of these new chemicals has a unique behavior and fate.

Some newly formed chemicals can have short half-lives and be quickly mineralized into their elemental building blocks. Other transformation products possess longer environmental half-lives and are stored or moved into other hydrologic compartments. Some are volatile and move into the atmosphere while some readily dissolve in water and move into the subsurface with infiltrating water or are transported with runoff to surface waters. Finally, some transformation products can become strongly associated with the sediment particles. In this case, the chemical can be transported with the particle, should it become remobilized. All of the transformation products described above could undergo further reactions and be transformed into second-generation transformation products. This process can continue until eventually all of the transformation products are reduced to their elemental building blocks. Depending on the specific chemical, the time to complete mineralization could range from fast (days or less) to slow (decades or more).

\section{Summary}

This framework provides a suite of conceptual tools to holistically address the effect of a broad range of agricultural chemicals and sediment on water quality across a variety of hydrologic settings. This framework can help effectively anticipate the effects of changes in agricultural activities on the protection or improvement of water quality in streams. Hydrologic settings are described in terms of their source of water to the stream, which is some combination of slowflow, fastflow, and drainflow. All chemicals and sediment fall on a continuum that ranges from being totally associated with water to totally associated with sediment. Chemicals with similar water-sediment affinities are transported by water movement in similar ways. Chemicals also fall along a transformation-rate continuum of environmental half-lives from short (minutes) to long (decades or more). A chemical's environmental half-life, relative to the hydrologic transit times of fields and watersheds, determines its distribution throughout the hydrologic environment. These are simplifications of the hydrologic setting and chemical behavior that can be used to improve and (or) protect water quality and as the basis for predicting the fate of a chemical removed by a trapping or conservation tillage management practice. These practices simply remove the chemical or sediment from the moving water and store it until it is remobilized or transformed. The stored sediment and chemicals are eventually remobilized and transported into the stream, affecting water quality, unless the chemicals were transformed or volatilized.

Few changes in agricultural activities can be effective for protecting water quality from all chemicals and sediment in all hydrological settings. Some changes can be effective; some can be counterproductive. In certain situations, water quality can be improved and protected by adding new, well-chosen agricultural activities or landscape modifications. In other situations, the removal of the existing landscape modifications, such as drainage, can be more effective.

The expectations for the effectiveness of an agricultural activity must consider the local hydrologic flowpaths within a specific field and the environmental behavior of the specific constituent - chemical or sediment - to be controlled. Although valuable knowledge can be gained from a generalized understanding, as in this conceptual framework, specific knowledge of the hydrology and chemistry is required for specific fields or watersheds. With specific knowledge, agricultural activities can be designed for optimal waterquality effects on a field-by-field basis. 


\section{References Cited}

Allison, J.D. and Allison, T.L., 2005, Partition coefficients for metals in surface water, soil, and waste: Washington, D.C., U.S. Environmental Protection Agency, July 2005, EPA/600/R-05-074; 93 p., accessed February 1, 2017, at https://nepis.epa.gov/Exe/ZyPDF.cgi/P1000GHE. PDF?Dockey=P1000GHE.PDF.

Andrus, J.M., Porter, M.D., Rodríguez, L.F., Kuehlhorn, Timothy, Cooke, R.A.C., Zhang, Yuanhui, Kent, A.D., and Zilles, J.L, 2014, Spatial variation in the bacterial and denitrifying bacterial community in a biofilter treating subsurface agricultural drainage, Microbial Ecology, v. 67, no. 2, p. 265-272, accessed February 1, 2017, at https://doi.org/10.1007/s00248-013-0286-0.

Arora, Kapil, Mickelson, S.K., Helmers, M.J., and Baker, J.L., 2010, Review of pesticide retention processes occurring in buffer strips receiving agricultural runoff: Journal of the American Water Resources Association, v. 46, no. 3,, p. 618-647, accessed February 1, 2017, at https://doi. org/10.1111/j.1752-1688.2010.00438.x.

Asmussen, L.E., White, A.W., Hauser, E.W., and Sheridan, J.M., 1976, Reduction of 2,4-D load in surface runoff down a grassed waterway: Journal of Environmental Quality, v. 6, no. 2, p. 159-162, accessed February 1, 2017, at https://doi.org/10.2134/ jeq1977.00472425000600020011x.

Aune, J.B, 2011, Conventional, organic and conservation agriculture: Production and environmental impact, chap. in Lichtfouse, Eric, ed., Agroecology and strategies for climate change: New York, Springer, Sustainable agriculture reviews series, v. 8, p. 149-168, accessed February 1, 2017, at https://doi.org/10.1007/978-94-007-1905-7_7.

Baker, J.L., Helmers, M.J., and Laflen, J.M., 2006a, Water management practices, rain-fed cropland, in Schnepf, Max and Cox, Craig, eds., Environmental benefits of conservation on cropland: The status of our knowledge: Ankeny, Iowa, Soil and Water Conservation Society, p. 89-130.

Baker, N.T., Stone, W.W., Wilson, J.T., and Meyer, M.T., 2006b, Occurrence and transport of agricultural chemicals in Leary Weber Ditch Basin, Hancock County, Indiana, 2003-04: U.S. Geological Survey Scientific Investigations Report 2006-5251, 44 p., accessed February 1, 2017, at https://pubs.usgs.gov/sir/2006/5251.

Baker, N.T., and Capel, P.D., 2011, Environmental factors that influence the location of crop agriculture in the conterminous United States: U.S. Geological Survey Scientific Investigations Report 2011-5108, 72 p., accessed February 1, 2017, at https://pubs.usgs.gov/sir/2011/5108/.
Barbarika, A. 2010. Conservation Reserve ProgramAnnual summary and enrollment statistics, FY10: Washington, D.C., Farm Service Agency, U.S. Department of Agriculture, 48 p., accessed June 19, 2015, at https:// www.fsa.usda.gov/Assets/USDA-FSA-Public/usdafiles/ Conservation/PDF/annual2010summary.pdf.

Barnett, J.R., Warner, R.C., Agouridis, C.T., and Edwards, D.R., 2010, Ability of a weep berm to enhance grass filter performance in a simulated grazed system: Preliminary Results, Journal of Natural \& Environmental Sciences, v. 1, no. 1, p.12-20, accessed February 1, 2017, at http:/www.academyjournal.net/asj/index.php/NES/article/ viewArticle/8.

Blann, K.L., Anderson, J.L., Sands, G.R. and Vondracek, Bruce, 2009, Effects of agricultural drainage on aquatic ecosystems - A review: Critical Reviews in Environmental Science and Technology, v. 39, no. 11, p. 909-1001, accessed February 1, 2017, at https://doi. org/10.1080/10643380801977966.

Budd, R., O’Geen, A., Goh, K.S., Bondarenko, S., and Gan, J., 2009, Efficacy of constructed wetlands in pesticide removal from tailwaters in the Central Valley, California: Environmental Science \& Technology, v. 43, no. 8, p. 2925 2930, accessed February 1, 2017, at https://doi.org/10.1021/ es802958q.

Canadian Centre for Environmental Modelling and Chemistry, 2004, Level I Model version 3.00, September 2004: Trent University Web page, accessed December 15, 2014, at https:/www.trentu.ca/academic/aminss/envmodel/models/ L1300.html.

Capel, P.D., 2017, Dataset used to develop a conceptual framework for effectively anticipating water-quality changes resulting from changes in agricultural activities: U.S. Geological Survey data release, https://doi. org/10.5066/F75T3HN9.

Capel, P. D., Ma, Lin, Schroyer, B. R., Larson, S. J., and Gilchrist, T. A., 1995, Analysis and detection of the new corn herbicide acetochlor in river water and rain: Environmental Science and Technology, v. 29, no. 6, p. 1702-1705, accessed February 1, 2017, at https://doi. org/10.1021/es00006a039.

Capel, P.D., McCarthy, K.A., Coupe, R.H., Grey, K.M., Amenumey, S.E., Baker, N.T., and Johnson, R.S., in press, Agriculture - A river runs through it - The connections between agriculture and water quality: U.S. Geological Survey Circular 1433, 207 p. 
Christensen, V.G., Lee, K.E., Sanocki, C.A., Mohring, E.H., and Kiesling, R.L., 2009, Water-quality and biological characteristics and responses to agricultural land retirement in three streams of the Minnesota River Basin, water years 2006-08: U.S. Geological Survey Scientific Investigations Report 2009-5215, 52 p., accessed February 1, 2017, at https://pubs.usgs.gov/sir/2009/5215.

City of Overland Park, 2015, Precipitation for 103rd Street at Indian Creek, City of Overland Park, Kansas, accessed September 25, 2015 at http://stormwatch.com.

Collischonn, W., and Fan, F.M., 2013, Defining parameters for Eckhardt's digital baseflow filter: Hydrologic Processes, v. 27, no. 18, p. 2614-2622, accessed February 1, 2017, at https://doi.org/10.1002/hyp.9391.

Cullum, R.F., 2009, Macropore flow estimations under no-till and till systems: CATENA, v. 78, no. 1, p. 87-91,accessed February 1, 2017, at https://doi.org/10.1016/j. catena.2009.03.004.

Dabney, S.M., 1998, Cover crop impacts on watershed hydrology: Journal of Soil and Water Conservation, v. 53, no. 3, p. 207-213, accessed February 1, 2017, at https:// www.jswconline.org/content/53/3/207.short.

Dachs, J., Van Ry, D. A., and Eisenreich, S. J., 1999, Occurrence of estrogenic nonylphenols in the urban and coastal atmosphere of the lower Hudson River estuary,: Environmental Science and Technology, v. 33, no. 15, p. 2676-2679, accessed February 1, 2017, at https://doi. org/10.1021/es990253w.

Delaware Environmental Observing System, 2015, Precipitation for Kenton, Delaware (http://www.deos.udel. edu/), accessed September 25, 2015 at http://www.deos. udel.edu.

De Liguoro, M., Cibin, V., Capolongo, F., Halling-Sørensen, B., Montesissa, C., 2003, Use of oxytetracycline and tylosin in intensive calf farming-Evaluation of transfer to manure and soil: Chemosphere, v. 52, no. 1, p. 203-212, accessed February 1, 2017, at https://doi.org/10.1016/s00456535(03)00284-4.

Devlin, D.L. and Barnes, P.L, 2009, Impacts of no-till on water quality: Manhattan, Kansas, Kansas State University, Agricultural Experiment Station and Cooperative Extension Service, MF-2907, 4 p., accessed June, 19, 2015, at http:// www.ksre.ksu.edu/bookstore/pubs/MF2907.pdf.

Dinnes, D.L., Karlen, D.L., Jaynes, D.B., Kaspar, T.C., Hatfield, J.L., Colvin, T.S., and Cambardella, C.A., 2002, Nitrogen management strategies to reduce nitrate leaching in tile-drained midwestern soils: Agronomy Journal, v. 94, no. 1, p. 153-171, accessed February 1, 2017, at https://doi. org/10.2134/agronj2002.0153.
Dubrovsky, N.M., Burow, K.R., Clark, G.M., Gronberg, J.M., Hamilton P.A., Hitt, K.J., Mueller, D.K., Munn, M.D., Nolan, B.T., Puckett, L.J., Rupert, M.G., Short, T.M., Spahr, N.E., Sprague, L.A., and Wilber, W.G., 2010, The quality of our Nation's waters-Nutrients in the Nation's streams and groundwater, 1992-2004: U.S. Geological Survey Circular 1350; 174 p., accessed February 1, 2017, at https://pubs. usgs.gov/circ/1350/.

Düring, R.-A., Krahe, Sebastian, and Gäth, Stefan, 2002, Sorption behavior of nonylphenol in terrestrial soils: Environmental Science and Technology, v. 36, no. 19, p. 4052-4057, accessed February 1, 2017, at https://doi. org/10.1021/es0103389.

Eckhardt, K., 2005, How to construct recursive digital filters for baseflow separation: Hydrologic Processes, v. 19, no. 2, p. 507-515, accessed February 1, 2017, at https://doi. org/10.1002/hyp.5675.

Eisenhauer, D.E., Bjornberg, D., and Westermann, D., 2006, Water management practices, irrigated cropland, in Schnepf, Max, and Cox, Craig, eds., Environmental benefits of conservation on cropland: The status of our knowledge: Ankeny, Iowa, Soil and Water Conservation Society, p. 131-148.

Evans, R.O., Skaggs, W.R., and Gilliam, J.W., 1995, Controlled versus conventional drainage effects on water quality: Journal of Irrigation and Drainage Engineering, v. 121, no. 4, p. 271-276, accessed February 1, 2017, at https://doi.org/10.1061/(ASCE)07339437(1995)121:4(271).

Feyereisen, G.W., Francesconi, Wendy, Smith, D.R., Papiernik, S.K., Krueger, E.S., and Wente, C.D., 2015, Effect of replacing surface inlets with blind or gravel inlets on sediment and phosphorus subsurface drainage losses: Journal of Environmental Quality, v. 44, no. 2, p. 594-604, accessed February 1, 2017, at https://doi.org/10.2134/ jeq2014.05.0219.

Fiener, P. and Auerswald, K., 2003, Effectiveness of grassed waterways in reducing runoff and sediment delivery from agricultural watersheds: Journal of Environmental Quality, v. 32, no. 3, p. 927-936, accessed February 1, 2017, at https://doi.org/10.2134/jeq2003.9270.

Flanagan, D.C., Ascough II, J.C., Nicks, A.D., Nearing, M.A., and Laflen, J.M., 1995, Overview of the WEPP erosion prediction model, chap. 1 in Flanagan, D.C., ed., Water erosion prediction project: Hillslope profile and watershed model documentation: West Lafayette, Indiana, National Soil Erosion Research Laboratory, U.S. Department of Agriculture, NSERL report no. 10, 12 p., accessed February 1, 2017, at https://www.ars.usda.gov/ ARSUserFiles/50201000/WEPP/chap1.pdf. 
Fuhrer, G.J., Morace, J.L., Johnson, H.M., Rinella, J.F., Ebbert, J.C., Embrey, S.S., Waite, I.R., Carpenter, K.D., Wise, D.R., and Hughes, C.A., 2004, Water quality in the Yakima River Basin, Washington, 1999-2000: U.S. Geological Survey Circular 1237, 34 p., accessed February 1, 2017, at https://pubs.water.usgs.gov/circ1237/.

Fiener, P. and Auerswald, K., 2003, Effectiveness of grassed waterways in reducing runoff and sediment delivery from agricultural watersheds: Journal of Environmental Quality, v. 32, no. 3, p. 927-936, accessed February 1, 2017, at https://doi.org/10.2134/jeq2003.9270.

Gilliom, R.J., Barbash, J.E., Crawford, C.G., Hamilton, P.A., Martin, J.D., Nakagaki, N., Nowell, L.H., Scott, J.C., Stackelberg, P.E., Thelin, G.P., and Wolock, D.M., 2006, Pesticides in the Nation's streams and groundwater, 1992-2001: U.S Geological Survey Circular 1291; 172 p., accessed February 1, 2017, at https:/pubs.usgs.gov/ circ/2005/1291/.

Gustafson, D.I., 2009, Groundwater ubiquity score: A simple method for assessing pesticide leachability: Environmental Toxicology and Chemistry, v. 8, no. 4, p. 339-357, accessed February 1, 2017, at https://doi.org/10.1002/ etc. 5620080411.

Hanson, B., Bond, C., Buhl, K. and Stone, D., 2015, Pesticide half-life fact sheet: Corvallis, Oreg., National Pesticide Information Center, Oregon State University Extension Services, 4 p., accessed November 20, 2015, at http://npic. orst.edu/factsheets/half-life.html.[Also available at http:// npic.orst.edu/factsheets/half-life.pdf].

Hesselsøe, M., Jensen, D., Skals, K., Olesen, T., Moldrup, P., Roslev, P., Mortensen, G.K., and Henriksen, K., 2001, Degradation of 4-nonylphenol in homogeneous and nonhomogeneous mixtures of soil and sewage sludge: Environmental Science and Technology, v. 35, no. 18, p. 3695-3700, accessed February 1, 2017, at https://doi. org/10.1021/es010024l.

Higgins, M.J., Rock, C.A., Bouchard, R., and Wengrezynek, B., 1993, Controlling agricultural runoff by use of constructed wetlands, in Moshiri, G.A., ed., Constructed wetlands for water quality improvement, Boca Raton, Fla., Lewis Publishers, p. 359-367.

Johnson, D.M., and Mueller, Richard, 2010, The 2009 cropland data layer: Photogrammetric Engineering \& Remote Sensing, v. 76, no. 11, p. 1201-1205.

Kalkhoff, S.J., Vecchia, A.V., Capel, P.D., and Meyer, M.T., 2012, Eleven-year trend in acetanilide pesticide degradates in the Iowa River, Iowa: Journal of Environmental Quality, v. 41, no. 5, p. 1566-1579, accessed February 1, 2017, at https://doi.org/10.2134/jeq2011.0426.
Kay, P., Blackwell, P.A., Boxall, A.B.A., 2004, Fate of veterinary antibiotics in a macroporous tile drained clay soil: Environmental Toxicology and Chemistry, v. 23, no. 5, p. 1136-1144, accessed February 1, 2017 at https://doi. org/10.1897/03-374.

Kell, W.V., and Brown, G.F., 1938, Strip cropping for soil conservation: U.S. Department of Agriculture, Farmers' Bulletin no. 1776, 37 p., accessed February 1, 2017, at http://hdl.handle.net/2027/uiug.30112019287363.

Kladivko, E.J., Van Scoyoc, G.E., Monke, E.J., Oates, K.M., and Pask, W., 1991, Pesticide and nutrient movement into subsurface tile drains on a silt loam soil in Indiana: Journal of Environmental Quality, v. 20, no. 1, p. 264-270, accessed February 1, 2017 at https://doi.org/10.2134/ jeq1991.00472425002000010043x.

Kleinman, P.J.A., Sharpley, A.N., Buda, A.R., McDowell, R.W., and Allen, A.L., 2011, Soil controls of phosphorus in runoff: Management barriers and opportunities. Canadian Journal of Soil Science, v. 91, no. 3, p. 329-338, accessed February 1, 2017, at https://doi. org/10.4141/CJSS09106.

Kohler, E.A., Poole, V.L., Reicher, Z.J., and Turco, R.F., 2004, Nutrient, metal, and pesticide removal during storm and nonstorm events by a constructed wetland on an urban golf course: Ecological Engineering, v. 23, nos. 4-5, p. 285-298, accessed February 1, 2017, at https://doi.org/10.1016/j. ecoleng.2004.11.002.

Komor, S.C and Magner, J.A., 1996, Nitrate in groundwater and water sources used by riparian trees in an agricultural watershed-A chemical and isotopic investigation in southern Minnesota: Water Resources Research, v. 32, no. 4, p. 1039-1050, accessed February 1, 2017, at https:// doi.org/10.1029/95wr03815.

Kronholm, S.C., and Capel, P.D., 2014, A comparison of high-resolution specific conductance-based end-member mixing analysis and a graphical method for baseflow separation of four streams in hydrologically challenging agricultural watersheds: Hydrological Processes, v. 29, no. 11, p. 2521-2533, accessed February 1, 2017, at https:// doi.org/10.1002/hyp.10378.

Lacas, J.-G., Voltz, M, Gouy, V,, Carluer, N, and Gril, J.-J., 2005, Using grassed strips to limit pesticide transfer to surface water-a review: Agronomy for Sustainable Development, v. 25, no. 2, p. 253-266, accessed February 1, 2017, at https://doi.org/10.1051/agro:2005001.

Lee, L.S., Strock, T.J., Sarmah, A.K., and Rao, P.S.C., 2003, Sorption and dissipation of testosterone, estrogens, and their primary transformation products in soils and sediment: Environmental Science and Technology, v. 37, no. 18, p. 4098-4105, accessed February 1, 2017, at https://doi. org/10.1021/es020998t. 
Lowrance, R., Isenhart, T.M., Gburek, W.J., Shields, F.D., Wiginton, P.J., and Dabney, S.M., 2006, Landscape management practices, in Schnepf, Max and Cox, Craig, eds., Environmental benefits of conservation on croplandThe status of our knowledge: Ankeny, Iowa, Soil and Water Conservation Society, p. 269-317.

Mackay, Donald, Shiu, W.-Y., Ma, K.-C., and Lee, S. C., 2006, Handbook of physical-chemical properties and environmental fate for organic chemicals, v. 4- Nitrogen and sulfur containing compounds and pesticides, (2d ed.): CRC Press, Boca Raton, Fla., p. 3195-4185,

Mapp, H.P., Bernardo, D.J., Sabbagh, G.J., Geleta, J., and Watkins, K.B., 1994, Economic and environmental impacts of limiting nitrogen use to protect water quality-A stochastic regional analysis: American Journal of Agricultural Economics, v. 76, no. 4, p. 889-903, accessed February 1, 2017, at https://doi.org/10.2307/1243749.

Marchand, L., Mench, M., Jacob, D.L., and Otte, M.L., 2010, Metal and metalloid removal in constructed wetlands, with emphasis on the importance of plants and standardized measurements - A review: Environmental Pollution, v. 158, no. 12, p. 3447-3461, accessed February 1, 2017, at https:// doi.org/10.1016/j.envpol.2010.08.018.

Margulies, Jared, 2012. No-till agriculture in the USA, chap. in Lichtfouse, E., ed., Organic fertilisation, soil quality and human health: Sustainable Agriculture Reviews, v. 9, p. 11-30, accessed February 1, 2017, at https://doi. org/10.1007/978-94-007-4113-3_2.

Mayer, P.M., Reynolds, Jr., S.K., McCutchen, M.D. and Canfield, T.J., 2006, Riparian buffer width, vegetative cover, and nitrogen removal effectiveness-A review of current science and regulations: Ada, Oklahoma, Office of Research and Development, Environmental Protection Agency EPA/600/R-05/118; 27 p., accessed February 1, 2017, at https://nepis.epa.gov/Exe/ZyPDF.cgi/2000O182. PDF?Dockey=2000O182.PDF.

Meals, D.W., Dressing, S.A., and Davenport, T.E., 2010, Lag time in water quality response to best management practices - A review: Journal of Environmental Quality, v. 39, no. 1, p. 85-96, accessed February 1, 2017, at https:// doi.org/10.2134/jeq2009.0108.

National Oceanic and Atmospheric Administration, 2015, Precipitation for Greenfield, Indiana, National Centers for Environmental Information, accessed September 25, 2015 at http://www.ncdc.noaa.gov.

Nodvin, S. C., Driscoll, C. T., Likens, G. E., 1986, Simple partitioning of anions and dissolved organic carbon in forest soil. Soil Science, v. 142, no. 1, p. 27-35, accessed February 1, 2017, at https://doi.org/10.1097/00010694198607000-00005.
Nowell, L.H., Capel, P.D., and Dileanis, P.D., 1999, Pesticides in stream sediment and aquatic biota-Distribution, trends, and governing factors: Boca Raton, Fla., CRC Press, Pesticides in the hydrologic system series, v. 4; 1,040 p.

Puckett, L.J., Tesoriero, A.J., and Dubrovsky, N.M., 2011, Nitrogen Contamination of Surficial Aquifers-A Growing Legacy: Environmental Science and Technology, v. 45, no. 3, 839-844, accessed February 1, 2017, at https://doi. org/10.1021/es1038358.

Reeder, R. and Westermann, D. 2006. Water Management Practices, Irrigated Cropland, in Schnepf, Max and Cox, Craig, eds., Environmental benefits of conservation on cropland: The status of our knowledge: Ankeny, Iowa, Soil and Water Conservation Society, p. 1-87.

Roth, J.L., 2010, Water, sediment, and nutrient transport from a drained topographical depression within an agricultural field in North-Central Iowa: Minneapolis, Minn., University of Minnesota, M.S.C.E. Thesis, 94 p., accessed September 27, 2015, at http://hdl.handle.net/11299/102695.

Roth, J.L., and Capel, P.D., 2012a, Changes in water budgets and sediment yields from a hypothetical agricultural field as a function of landscape and management characteristics-A unit field modeling approach: U.S. Geological Survey Scientific Investigation Report 2012-5203, 42 p., accessed February 1, 2017, at https://pubs.usgs.gov/sir/2012/5203/.

Roth, J.L. and Capel, P.D., 2012b, The hydrology of a drained topographical depression within an agricultural field in North-Central Iowa: Transactions of the American Society of Agricultural and Biological Engineers, v. 55, no. 5, p. 1801-1814, accessed February 1, 2017, at https://doi. org/10.13031/2013.42367.

Sanford, W.E. and Pope, J.P., 2013, Quantifying groundwater's role in delaying improvements to Chesapeake Bay water quality: Environmental Science and Technology, v. 47, no. 23, p. 13330-13338, accessed February 1, 2017, at https://doi.org/10.1021/es401334k.

Schipper, L.A., Robertson, W.D., Gold, A.J., Janyes, D.B., and Cameron, S.C. 2010. Denitrifying bioreactors-An approach for reducing nitrate loads to receiving waters: Ecological Engineering, v. 36, no. 11, p. 1532-1543, accessed February 1, 2017, at https://doi.org/10.1016/j. ecoleng.2010.04.008.

Shah, J.V., 2006, Distribution of phosphorous and nitrogen between solids and water in surface water environment. Minneapolis, Minn., University of Minnesota, M.S.C.E. Thesis, $94 \mathrm{p}$. 
Sharpley, A.N., Weld, J.L., Beegle, D.B., Kleinman, P.J.A., Gburek, W.J., Moore, P.A. Jr., and Mullins, G., 2003, Development of phosphorus indices for nutrient management planning strategies in the United States: Journal of Soil and Water Conservation, v. 58, no. 3, p. 137152, accessed February 1, 2017, at http://www.jswconline. org/content/58/3/137.

Sharpley, A., Jarvie, H.P., Buda, A., May, L., Spears, B., and Kleinman, P., 2013, Phosphorus legacy-Overcoming the effects of past management practices to mitigate future water quality impairment: Journal of Environmental Quality, v. 42, no. 5, p. 1308-1326, accessed February 1, 2017, at https://doi.org/10.2134/jeq2013.03.0098.

Sloto, R.A. and Crouse, M.Y., 1996, HYSEP: A computer program for streamflow hydrograph separation and analysis: U.S. Geological Survey Water-Resources Investigations Report 96-4040, 46 p, accessed February 1, 2017, at https:// pubs.er.usgs.gov/publication/wri964040.

Smith, T.A., Osmond, D.L., and Gilliam, J.W., 2006, Riparian buffer width and nitrate removal in a lagoon-effluent irrigated agricultural area: Journal of Soil and Water Conservation, v. 61, no. 5, p. 273-281, accessed February 1, 2017, at http://www.jswconline.org/content/61/5/273.short.

Sullivan, D.J., Vecchia, A.V., Lorenz, D.L., Gilliom, R.J., and Martin, J.D., 2009, Trends in pesticide concentrations in corn-belt streams, 1996-2006: U.S. Geological Survey Scientific Investigations Report 2009-5132, 75 p., accessed February 1, 2017, at https://pubs.usgs.gov/sir/2009/5132/.

Ter Laak, T. L., Gebbink, W. A., and Tolles, Johannes, 2006, The effect of $\mathrm{pH}$ and ionic strength on the sorption of sulfachloropyridazine, tylosin and oxytetracycline to soil: Environmental Toxicology and Chemistry, v. 25, no. 4, p. 904-911, accessed February 1, 2017, at https://doi. org/10.1897/05-232r.1.

Teiter, S., and Mander, Ü., 2005, Emission of $\mathrm{N}_{2} \mathrm{O}, \mathrm{N}_{2}$, $\mathrm{CH}_{4}$, and $\mathrm{CO}_{2}$ from constructed wetlands for wastewater treatment and from riparian buffer zones: Ecological Engineering, v. 25, no. 5, p. 528-541, accessed February 1, 2017, at https://doi.org/10.1016/j.ecoleng.2005.07.011.

U.S. Department of Agriculture, 2001, The ARS Pesticide Properties Database:, Agricultural Research Service, U.S. Department of Agriculture, accessed December 15, 2014, at https://www.ars.usda.gov/northeast-area/beltsville-md/ beltsville-agricultural-research-center/crop-systems-andglobal-change-laboratory/docs/ppd/pesticide-propertiesdatabase/.

U.S. Department of Agriculture, 2014a, National conservation practice standards: Natural Resources Conservation Service Web page, accessed December 15, 2014, at http://www. nrcs.usda.gov/wps/portal/nrcs/detailfull/national/technical/ references/?cid=nrcsdev11_001020.
U.S. Department of Agriculture, 2014b, Conservation Reserve Program: Natural Resources Conservation Service Web page, accessed September 20, 2014, at http://www.nrcs. usda.gov/wps/portal/nrcs/detail/national/technical/nra/ ceap/?cid=stelprdb1041269.

U.S. Department of Agriculture, 2015a, National resources inventory: Natural Resources Conservation Service Web page, accessed April 8, 2015, at http://www.nrcs.usda.gov/ wps/portal/nrcs/main/national/technical/nra/nri/.

U.S. Department of Agriculture, 2015b, Field office technical guide (FOTG), Section V-Conservation effects, conservation practice physical effects (CPPE): Natural Resources Conservation Service Web page, accessed April 8, 2015, at http://www.nrcs.usda.gov/wps/portal/nrcs/ main/national/technical/fotg/.

U.S. Department of Agriculture, 2015c, Description of STATSGO2 database: Natural Resources Conservation Service Web page, accessed September 20, 2015, at http:// www.nrcs.usda.gov/wps/portal/nrcs/detail/soils/survey/ geo/?cid=nrcs142p2_053629.

U.S. Environmental Protection Agency, 2003, Management Practices, chap. 3 in National management measures to control nonpoint source pollution from agriculture, EPA 841-B-03-004, p. 3-31-3-36, accessed February 1, 2017, at https://www.epa.gov/sites/production/files/2015-10/ documents/chap3_0.pdf.

Velkoverh, J.L., Capel, P.D., and Hopple, J.A., 2016, Selected chemicals that are associated with agricultural activities: U.S. Geological Survey data release, https://doi. org/10.5066/F7348HGF.

Verbree, D.A., Duiker, S.W., and Kleinman, P.J. 2010. Runoff losses of sediment and phosphorus from no-till and cultivated soils receiving dairy manure: Journal of Environmental Quality, v. 39, no. 5, p. 1762-1770, accessed February 1, 2017, at https://doi.org/10.2134/jeq2010.0032.

Vymazal, J. and Březinová, T., 2015, The use of constructed wetlands for removal of pesticides from agricultural runoff and drainage: A review: Environment International, v. 75, Feb., p. 11-20, accessed February 1, 2017, at https://doi. org/10.1016/j.envint.2014.10.026.

Wahl, K.L., and T.L. Wahl. 1995. Determining the flow of Comal Springs at New Braunfels, Texas. In Proceedings of Texas Water '95. A Component Conference of the First International Conference on Water Resources Engineering, August 16-17, 1995, ed. M.E. Jennings, Q.W. Martin, and T.R. Knowles, 77-86. San Antonio, Texas: American Society of Civil Engineers. 
Webb, R.M.T., Wieczorek, M.E., Nolan, B.T., Hancock, T.C., Sandstrom, M.W., Barbash, J.E., Bayless, E.R., Healy, R.W., and Linard, J., 2008, Variations in pesticide leaching related to land use, pesticide properties, and unsaturated zone thickness: Journal of Environmental Quality, v. 37, no. 3, p. 1145-1157, accessed February 1, 2017, at https:// dl.sciencesocieties.org/publications/jeq/abstracts/37/3/1145.

Wieczorek, M., 2004, Subsurface drains on agricultural land in the conterminous United States, 1992-National resource inventory conservation practice 606 (ver. 1.1, February 19, 2002): U.S. Geological Survey Water Resources NSDI Node, accessed February 1, 2017, at https://water.usgs.gov/ GIS/metadata/usgswrd/XML/nri92_cp606.xml.

Wolock, D.M., 2003, Base-flow index grid for the conterminous United States: U.S. Geological Survey OpenFile Report 03-263, accessed February 1, 2017, at https:// pubs.er.usgs.gov/publication/ofr03263.

Woolhiser, D.D., Smith, R.E., and Goodrich, D.C., 1990, KINEROS, A kinematic runoff and erosion model: Documentation and user manual: Washington, D.C., Agricultural Research Service, U.S. Department of Agriculture, ARS-77, 130 p., accessed December 15, 2014, at http://www.tucson.ars.ag.gov/unit/Publications/ PDFfiles/703.pdf.

Wortmann, C., Morton, L.W., Helmers, M., Ingels, C., Devlin, D., Roe, J., McCann, L., and Van Liew, M., 2011, Cost effective water quality protection in the Midwest: Lincoln, Nebraska, Heartland Regional Water Coordination Initiative, University of Nebraska-Lincoln Extension, RP197, 22 p., accessed June 19, 2015, at http:// extensionpublications.unl.edu/assets/pdf/rp197.pdf.

Wortmann, C., Shapiro, C., Helmers, M., Mallarino, A., Barden, C., Devlin, D., Pierzynski, G., Lory, J., Massey, R., and Kovar, J., 2013a, Agricultural phosphorus management and water quality protection in the Midwest: Lincoln, Nebraska, Heartland Regional Water Coordination Initiative, University of Nebraska-Lincoln Extension, RP187, 24 p., accessed June 19, 2015, at http:// extensionpublications.unl.edu/assets/pdf/rp187.pdf.
Wortmann, C., Al-Kaisi, M., Helmers, M., Sawyer, J., Devlin, D., Barden, C., Scharf, P., Ferguson, R., Kranz, W., Shapiro, C., Spalding, R., Tarkalson, D., Holz, J., Francis, D., and Schepers, J., 2013b, Agricultural nitrogen management for water quality protection in the Midwest: Lincoln, Nebraska, Heartland Regional Water Coordination Initiative, University of Nebraska-Lincoln Extension, RP189, 31 p., accessed June 19, 2015, at http:// extensionpublications.unl.edu/assets/pdf/rp189.pdf.

Zebarth, B. J., Ryan, M. C., Graham, Gwyn, Forge, T. A. and Neilsen, Denise, 2015a, Groundwater monitoring to support development of BMPs for groundwater protection: The Abbotsford-Sumas Aquifer case study: Groundwater Monitoring \& Remediation, v. 35, no. 1, p. 82-96, accessed February 1, 2017, at http://onlinelibrary.wiley.com/ doi/10.1111/gwmr.12092/abstract.

Zebarth, B.J., Danielescu, Serban, Nyiraneza, Judith, Ryan, M.C., Jiang, Yefang, Grimmett, Mark and Burton, D.L., 2015b, Controls on nitrate loading and implications for BMPs under intensive potato production systems in Prince Edward Island, Canada: Groundwater Monitoring \& Remediation, v. 35, no. 1, p. 30-42, accessed February 1, 2017, at http://onlinelibrary.wiley.com/ doi/10.1111/gwmr.12088/full.

Zuazo, V.H.D and Pleguezuelo, C.R.R., 2002, Soil-erosion and runoff prevention by plant covers-A review: Agronomy for Sustainable Development, v. 28, no. 1, p. 65-86, accessed February 1, 2017 http://link.springer.com/article/10.1051/ agro:2007062. 


\section{Appendixes 1-5}




\section{Appendix 1. National Map of Important Flowpaths}

The national map of important flowpaths (fig. 3) was created by systematically categorizing the conterminous United States into nonagricultural land and agricultural land. The agricultural land was then categorized into four distinct classes based on calculated baseflow indexes (BFI) and the presence of four subsurface drainage classes: drainflow, fastflow, slowflow, mixed flow.

The map was created by combining three existing Geographic Information System (GIS) datasets. Agricultural land is based on the U.S. Department of Agriculture's 2009 Cropland Data Layer (CDL) (Johnson and Mueller, 2010). The subsurface drainage portion of the map is based on the method developed by Baker and Capel (2011) using the U.S. Department of Agriculture, Natural Resources Conservation Service (2015c) State Soil Geographic (STATSGO) dataset (specifically, the soils hazard class "Water" in the Component table) combined with the 1992 Natural Resources Inventory (NRI) county-level conservation practice raster dataset (c606 - subsurface drainage; Wieczorek, 2004). The delineation between fastflow and slowflow are based on a dataset of baseflow index values (Wolock, 2003).
The national map shows important flowpaths only on agricultural land as represented on the 2009 CDL grid. The flowpath categories were based on 1-kilometer resolution conterminous United States geospatial grids of baseflow index values (Wolock, 2003). The flowpath categories were set initially so that fastflow grid cells were defined as those grid cells with BFI values in the $0-40$ percent range, mixed flow grid cells had BFI values in the 41-49 percent range, and slowflow grid cells had BFI values greater than 50 percent. Based on the NRI (U.S. Department of Agriculture, Natural Resources Conservation Service, 2015a), grid cells that contained subsurface drainage $>0$ were classified as drainflow grid cells, regardless of the associated BFI value. When surface drains (channels) were present, they were considered part of the stream network and were not included in drainflow. The surface drains were assumed to collect fastflow.

The set of decisions used in the formation of this map creates a coarse approximation of the important flowpaths for areas across the Nation. However, the flowpath for any grid cell is uncertain. In the upper Midwest (prairie pothole region), fastflow can collect in topographical depressions in the landscape (often wetlands) rather than flow directly to the stream. 


\section{Appendix 2. Maps of Hydrologic Transit Times in Small Watersheds}

Maps of hydrologic transit times were developed for three small watersheds: (a) Chesterville Branch, Maryland (01493112); (b) Indian Creek, Kansas (06893390); and (c) Leary-Weber Ditch, Indiana (03361638). The estimated transit time values for Chesterville Branch and Indian Creek were developed from digital elevation model (DEM) data and the 1:100,000-scale National Hydrography Dataset (NHD). In the case of Leary-Weber Ditch, a map indicating the location of the subsurface drain network was used instead of NHD streams (Baker and others, 2006b). The grid-cell resolution of the DEMs was 30 meters $(\mathrm{m})$ for Chesterville Branch and Leary-Weber Ditch and $100 \mathrm{~m}$ for Indian Creek. The analysis method used was not sensitive to the resolution of the DEMs.

The transit time analysis is based on the datasets mentioned above and, most importantly, assumptions about the characteristic flowpath and velocity of water in each watershed.

In Chesterville Branch, it was assumed that groundwater discharge was the characteristic source of streamflow and its flow velocity through the subsurface was assumed to be 0.1 meter per day $(\mathrm{m} / \mathrm{d})$. In Indian Creek, overland flow was assumed to be the main source of streamflow and its flow velocity over the land surface was assumed to be 200 meters per hour (m/h). In Leary-Weber Ditch, it was assumed that flow through subsurface tile drains was the characteristic source of streamflow. Infiltrating water was assumed to move to subsurface drains as rapid horizontal flow with a velocity of $20 \mathrm{~m} / \mathrm{hr}$ and then quickly move through subsurface drains with no additional travel time.
The processing steps used for each watershed were completed using the GRID module in Esri Arc 9.2 for Unix workstations:

1. Use the FILL command to remove the local sinks in the DEM and generate a flow direction grid.

2. Use the FLOWACCUMULATION command to generate a flow accumulation grid.

3. Overlay the NHD line coverage on the flow accumulation grid to estimate a threshold for stream channel initiation. This step was not done for LearyWeber.

4. Set the grid cells in the flow direction grid with associated flow accumulation values greater than the stream channel initiation threshold to NODATA. For Leary-Weber, all flow direction grid cells overlaying subsurface tile drains were set to NODATA.

5. Use the FLOWLENGTH command with the DOWNSTREAM option to generate a grid indicating the distance from each grid cell in the watershed to a stream (or tile drain in the case of Leary-Weber).

6. Divide the distance grid by the assumed flow velocity to compute the transit time value. 


\section{Appendix 3. Extent of Association with Sediment and Environmental Half-Lives for Selected Chemicals Related to Agriculture}

Chemicals entering the environment tend to distribute into environmental compartments in a predictable manner. By combining the properties of a compound with the properties of the environment, the behavior of the compound in that environment can be predicted. Properties important in this regard include solubility, vapor pressure, and partitioning coefficients. These properties are combined with environmental properties to estimate where compounds can be found in the environment. The compounds included here are relevant to agricultural systems as either chemicals used to promote the growth and health of crops and livestock or as byproducts from the practice of growing crops and livestock.

Fugacity modeling is commonly used to estimate the distribution of a chemical among hydrological compartments (Mackay and others, 2006). Level 1 fugacity models describe the distribution of compounds at static equilibrium. These models are relatively simple and use a small number of variables to describe a compound's behavior. Chemical reactions, or removal or addition of the compound to an environment, are not considered in Level 1 models. The fugacity model is used here to predict the distribution of chemicals between water and sediment at equilibrium.

The Fugacity Level 1 Model v. 3.00 computer program, produced by the Canadian Centre for Environmental
Modelling and Chemistry (2004), was used in these calculations. Within the model, a chemical "Specimen Type 1" profile was used for all chemicals. The modeled environment was composed of only water and suspended sediment (particles; table A3-1). All chemicals were described by sediment-water distribution coefficient $(\mathrm{Kd})$ in the fugacity calculations (table A3-2). For the organic chemicals (pesticides, antibiotics, and estrogens), the Kd values were calculated as the product of the chemical's organic-carbon normalized distribution coefficient (Koc) values from the literature and the fraction of organic carbon assigned to the sediment (Mackay and others, 2006). For inorganic chemicals (cations and anions), the Kd values were used as reported in the literature. Sediment and bacteria were defined as being completely in the particulate phase (100 percent sediment associated).

A typical, pseudo-first-order environmental half-life (days) was obtained from the literature (U.S. Department of Agriculture, 2001; Mackay and others, 2006; table 5). The transformation rates for antibiotic and estrogenic compounds were taken from soil or soil-water systems (Hesselsøe and others, 2001; Lee and others, 2003; De Liguoro and others, 2003; Kay and others, 2004). No degradation was assumed to occur for metals.

Table A3-1. Environmental properties assumed for the Level 1 fugacity calculations.

[Environmental properties: The volumes of other possible environmental compartments (air, aerosol, fish, soil, bed sediment) were set equal to $1 \times 10^{-20} \mathrm{~m}^{3}$ so they would be negligible in the fugacity calculations]

\begin{tabular}{|c|c|c|c|}
\hline & $\begin{array}{c}\text { Volume } \\
\left(\mathrm{m}^{3}\right)\end{array}$ & $\begin{array}{l}\text { Density } \\
\left(\mathrm{kg} / \mathrm{m}^{3}\right)\end{array}$ & $\begin{array}{c}\text { Organic carbon } \\
(\mathrm{g} / \mathrm{g})\end{array}$ \\
\hline Water & 1,000 & 1,000 & Not applicable \\
\hline Suspended particles & 12 & 1,500 & 0.2 \\
\hline
\end{tabular}

${ }^{1}$ This is equal to a suspended sediment of $3,000 \mathrm{mg} / \mathrm{L}$, mimicking runoff water from a field after a storm event. 
Table A3-2. Distribution coefficients, environmental half-lives, and calculated percent associated with sediment for selected chemicals.

[foc: fraction, organic carbon, $0.02=0.2 \mathrm{~g}$ organic carbon $/ \mathrm{g}$ sediment]

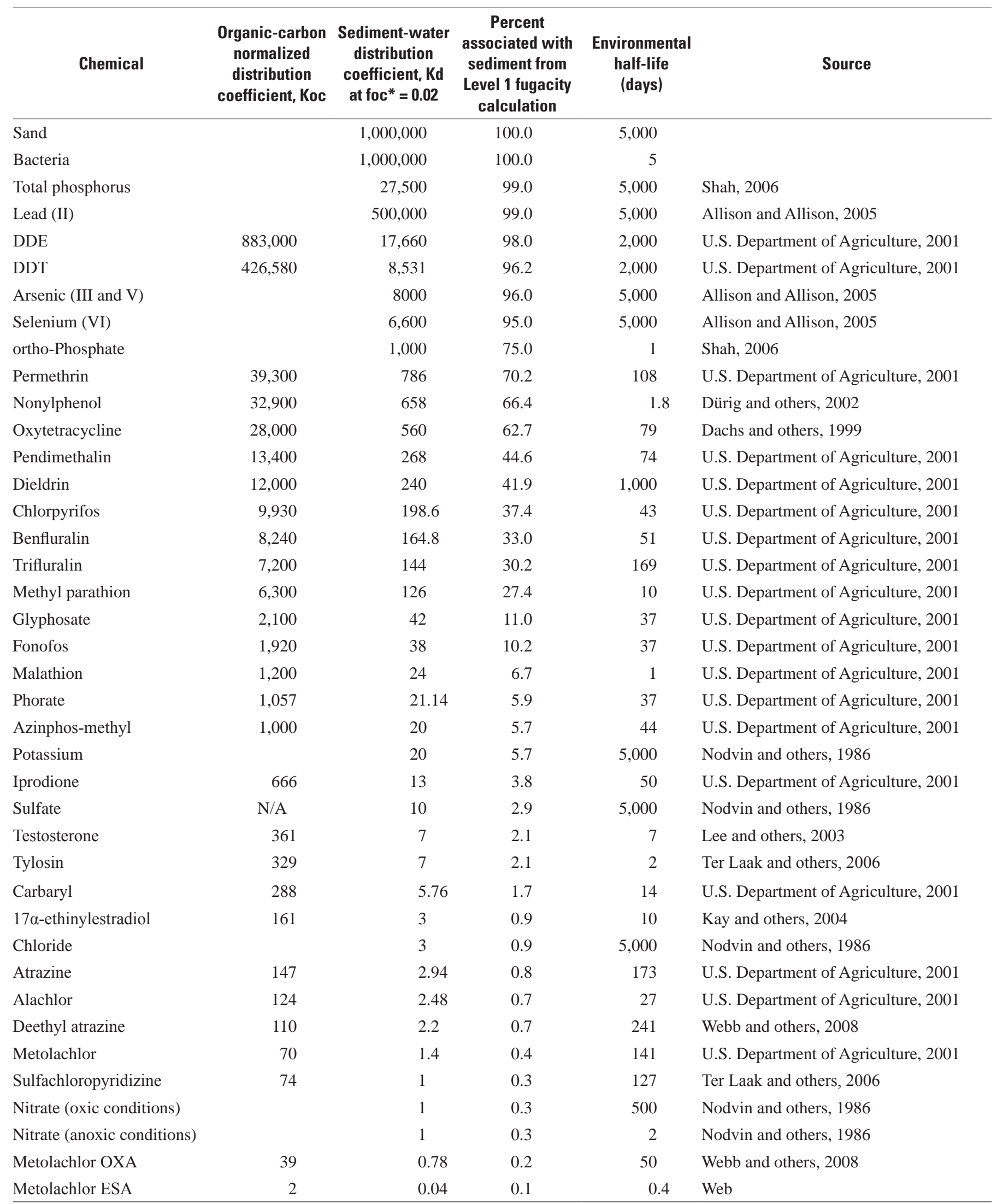




\section{Appendix 4. Selected Studies of the Effect of Agricultural Management Practices on the Movement of Chemicals and Sediments Out of the Field}

Table A4-1. Selected studies of the effect of agricultural management practices on the movement of chemicals and sediments out of the field.

[Abbreviations: BOD, biochemical oxygen demand; GHG, greenhouse gasses; N, nitrogen; P, phosphorus; SS, suspended sediment]

\begin{tabular}{|c|c|c|c|}
\hline & Productive & Counterproductive & Comments \\
\hline \multicolumn{4}{|c|}{ Trapping practices } \\
\hline Terraces & P, SS: Wortmann, 2013a & - & $\begin{array}{l}\text { Chemicals and sediment can be } \\
\text { transported through the outlet } \\
\text { drains from some terraces. }\end{array}$ \\
\hline Grassed waterways & $\begin{array}{l}\text { P: Wortmann, 2013a; } \\
\text { SS: Fiener and Auerswald, 2003; } \\
\text { Pesticides: Asmussen and others, } \\
\quad 1976\end{array}$ & - & \\
\hline Buffer/filter strips & $\begin{array}{l}\text { N: Smith and others, 2006, Mayer } \\
\text { and others, 2006, Dinnes and } \\
\text { others, 2002; } \\
\text { P: Wortmann, 2013a, Wortmann, } \\
\text { 2011; SS: Wortmann, 2011; } \\
\text { Pesticides: Arora and others, 2010, } \\
\text { Lacas and others, } 2005 .\end{array}$ & - & $\begin{array}{l}\text { Plants in the buffer strip can } \\
\text { remove N from shallow } \\
\text { groundwater, Wortmann, 2013b; } \\
\text { Komor and Magner, } 1996\end{array}$ \\
\hline $\begin{array}{l}\text { Weep berms (earth banks at } \\
\text { field boundaries) }\end{array}$ & P, SS: Barnett and others, 2010 & - & $\begin{array}{l}\text { No studies were found that } \\
\text { discussed the possible } \\
\text { counterproductive effects of } \\
\text { berms }\end{array}$ \\
\hline Cover crops & $\begin{array}{l}\text { N: Wortmann, 2013b, Dinnes and } \\
\text { others, 2002; P: Wortmann, 2013a; } \\
\text { Wortmann, } 2011 \\
\text { SS: Zuazo and Pleguezuelo, 2002; } \\
\quad \text { Water: Dabney, } 1998\end{array}$ & - & \\
\hline \multicolumn{4}{|c|}{ Tillage practices } \\
\hline Contoured plowing & $\begin{array}{l}\text { N: Wortmann (2011); } \\
\text { P: Wortmann (2011); }\end{array}$ & - & \\
\hline Strip cropping & SS: Kell and Brown, 1938 & P: Verbree and others, 2010 & \\
\hline
\end{tabular}


Table A4-1. Selected studies of the effect of agricultural management practices on the movement of chemicals and sediments out of the field.-Continued

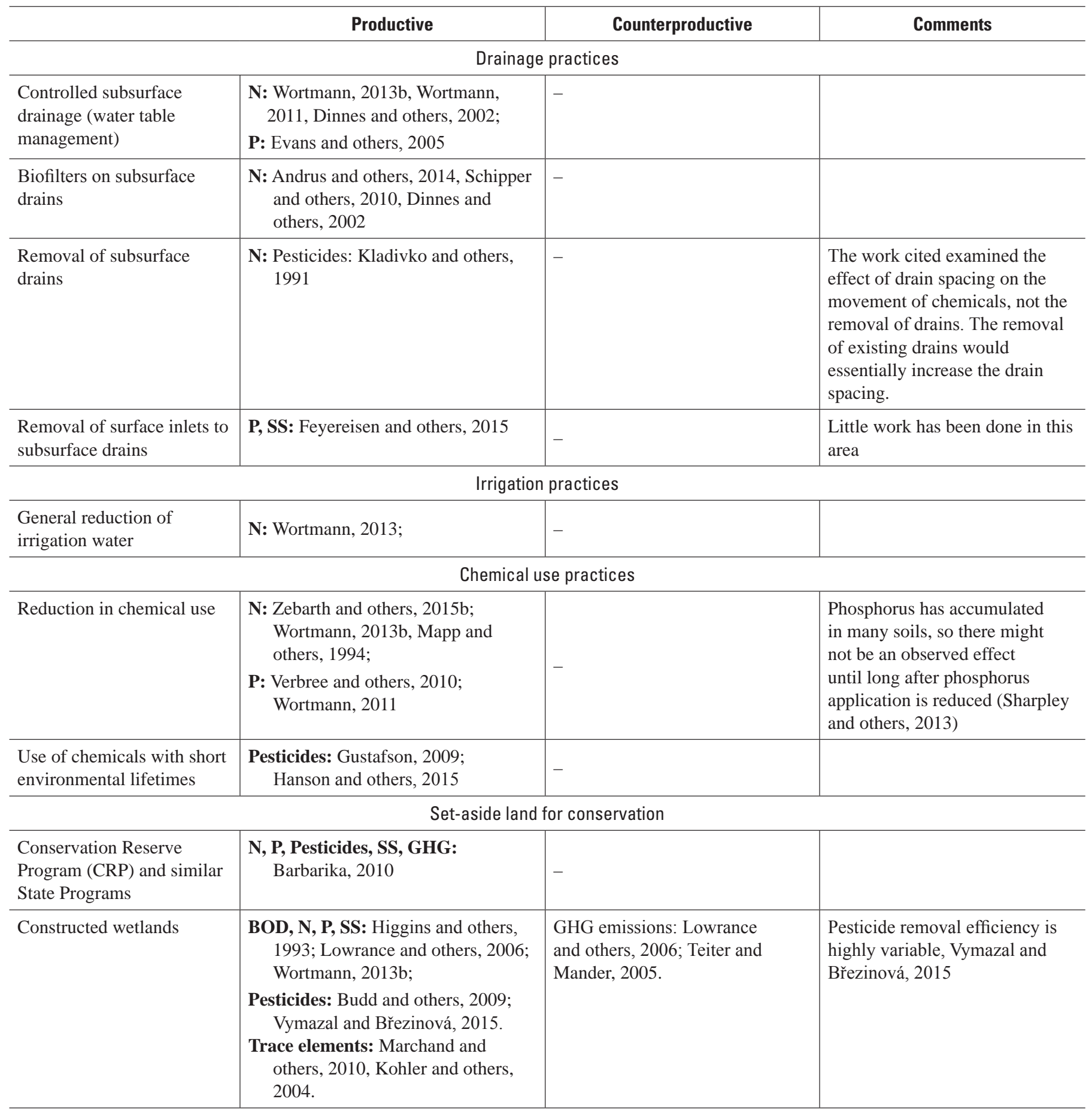




\section{Appendix 5. Agricultural Activity Decision Tree as an Organizing Tool Including Vertical Inlets to Subsurface Drains}

The decision tree in figure 9 has three basic questions that can be extended to include the effects of vertical inlets to subsurface drainage. The first question centers on the environmental behavior of the chemical of concern: Is the chemical of concern primarily associated with sediment? The second question addresses the presence of vertical inlets to subsurface drains that link the landscape directly to the stream via the subsurface drainage network. The third question asks: Is the water moving through subsurface drainage? The final question pertains to the nature of the hydrologic setting: Is the water moving through groundwater? The answers to these four questions can guide the choice and expectations of effectiveness in implementing an agricultural activity. 


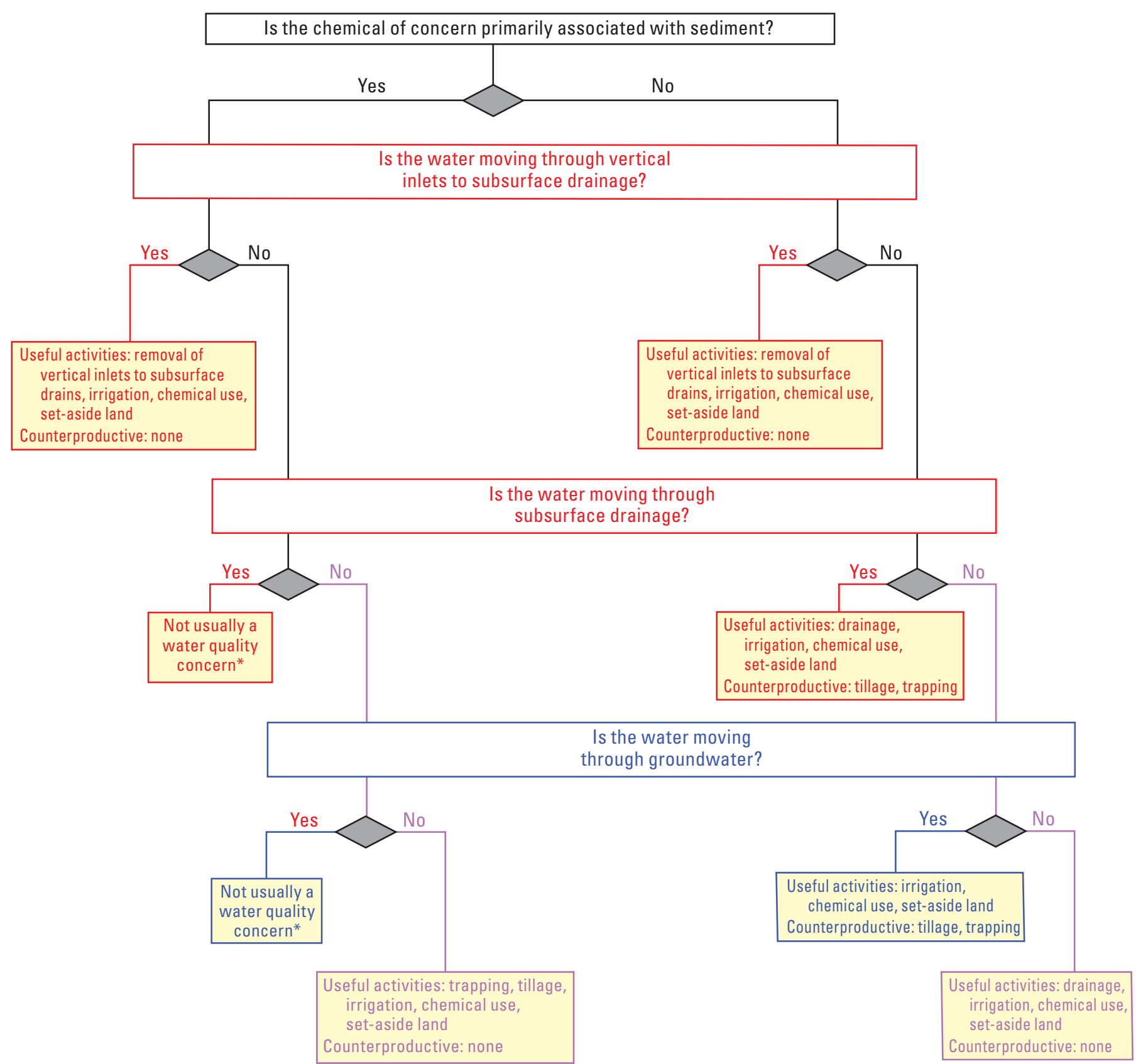

\section{EXPLANATION}

\section{Slowflow paths \\ Fastflow paths \\ Drainflow paths}

Figure A5-1. A simple decision tree that includes the effect of vertical inlets to subsurface drainage for determining the agricultural activities that could protect and (or) improve water quality in the local stream from the leakage of a specific chemical (or sediment) and those that could be counterproductive. The groups of agricultural activities considered are listed in table 3 . The asterisk $\left(^{*}\right)$ denotes chemicals that do not usually cause a water quality concern from the portion of the water moving through subsurface flowpaths (for example, moving through soil to groundwater or subsurface drains), but they can cause a concern with the portion of water moving through surface flowpaths. 

Publishing support provided by the U.S. Geological Survey

Science Publishing Network, Reston and Tacoma Publishing Service Centers

For more information concerning the research in this report, contact the

National Water-Quality Program

U.S. Geological Survey

12201 Sunrise Valley Drive

Reston, VA 20192

or visit our Web site at:

https://www.usgs.gov/science/mission-areas/water/national-water-quality-program. 
